\title{
Site investigation of masonry buildings damaged during the 23 October and 9 November 2011 Van Earthquakes in Turkey
}

\author{
F. Piroglu and K. Ozakgul \\ Dept. of Civil Engineering, Istanbul Technical University, 34469 Maslak, Istanbul, Turkey \\ Correspondence to: K. Ozakgul (ozakgulk@itu.edu.tr) \\ Received: 25 November 2012 - Published in Nat. Hazards Earth Syst. Sci. Discuss.: - \\ Revised: 15 January 2013 - Accepted: 16 January 2013 - Published: 20 March 2013
}

\begin{abstract}
The purpose of this study is to scrutinize and interpret the damages to masonry buildings after a series of earthquakes that occurred in Van, which is an eastern city of Turkey, within 17 days in 2011, i.e., the first earthquake hit on 23 October having the magnitude 7.1, and the second on 9 November with the magnitude 5.6 on the Richter scale. These consecutive earthquakes and their aftershocks caused extensive damage and the collapse of buildings in the city of Van and its villages and especially its near town, namely Ercis. For the investigation of masonry buildings, Hacibekir district, which is one of the regions comprising the highest density of masonry buildings in the city of Van, was selected and the seismic performance of these buildings was observed, tested in the field, and interpreted according to the Turkish earthquake-resistant design codes. In this region, masonry buildings were classified as adobe, unreinforced and confined masonry buildings. As a result of this field study, it was observed that whereas the confined masonry buildings had usually shown good performance during the earthquakes, the adobe and the unreinforced masonry buildings were seriously damaged and some of them were partially collapsed.
\end{abstract}

\section{Introduction}

Van city is one of the biggest eastern cities of Turkey, is approximately $1725 \mathrm{~m}$ a.s.l. and built at a distance of about 4$5 \mathrm{~km}$ from the eastern side of Lake Van, which has a surface area of $3713 \mathrm{~km}^{2}$ (see Fig. 1). This city also has a historical heritage and was the capital city of the kingdom of Urartu in the 7-8th centuries BC. The present population of the city is about 400000 (The Governorship of Van, 2012).
At 13:41 LT on 23 October 2011, a disastrous earthquake occurred approximately $20 \mathrm{~km}$ north of the city of Van (USGS, 2012). According to the US Geological Survey (USGS, 2012), the moment magnitude of the earthquake $M_{\mathrm{w}}$ was 7.1 , its depth was $16 \mathrm{~km}$, and the epicenter location was given as $38.691^{\circ} \mathrm{N}, 43.497^{\circ} \mathrm{E}$ between Kasimoglu Village and the west side of Lake Ercek, as shown in Fig. 2. In the region affected by this earthquake, the distribution of the peak acceleration of the ground motion was as given in Fig. 3 (USGS, 2012). Based on the preliminary investigations conducted on the field after this earthquake, surface faulting, ground deformations, liquefaction and fallen rocks were reported by the Disaster and Emergency Management Presidency of Turkey (AFAD, 2012). In this earthquake, Van city and Ercis, which is a town about $100 \mathrm{~km}$ north of the center of Van, and their surrounding villages were badly affected: at least 604 people died, about 1300 people were injured, about 2000 buildings collapsed, and after the mainshock 6284 aftershocks with magnitudes of 1.7 to 5.8 were recorded in total until 9 December 2011 (AFAD, 2012).

On 9 November 2011, another earthquake occurred after 17 days at 21:23 LT (USGS, 2012). The magnitude of this earthquake $\left(M_{\mathrm{w}}\right)$ was 5.6, and its epicenter, which was at $38.429^{\circ} \mathrm{N}, 43.229^{\circ} \mathrm{E}$, was located about $15 \mathrm{~km}$ to the south of Van, near the town of Edremit, at a depth of $5 \mathrm{~km}$ (USGS, 2012), as given in Fig. 2. It was reported that this second earthquake caused the loss of 40 lives and the collapse of 25 buildings in Van (USGS, 2012; AFAD, 2012). The ground motion generated by this earthquake is presented by using the shaking and the acceleration maps (USGS, 2012), as seen in Fig. 4.

According to the seismic hazard map (USGS, 2012), Van province is one of the highest seismic regions in eastern 


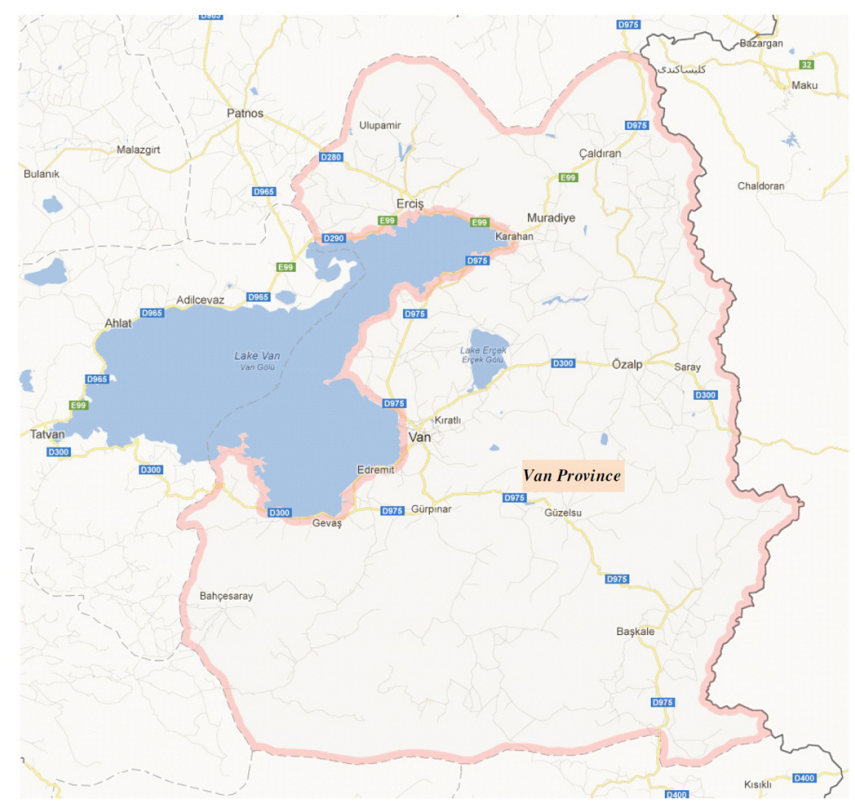

Fig. 1. Map of Van Province.

Turkey, as seen from Fig. 5. The historical seismicity of Van city and its vicinity regions since 1900 is given in Fig. 6 (USGS, 2012). Earthquakes that occurred in the eastern Anatolian region in the years from 2000 have been investigated by researchers (Kaplan et al., 2004; Bayraktar et al., 2007; Binici, 2007; Celep et al., 2011; Cetinkaya, 2011; Sayin et al., 2012). In this region earthquakes are extensively produced by the collision of the Arabian and Eurasian plates. As can be seen in Fig. 7, the Anatolian block is surrounded by the northern and eastern Anatolian main fault zones. These earthquakes were generated by tectonic deformations dominated by the eastern extent of North Anatolian Fault Zone with strike-slip faulting and additionally by the Bitlis-Zagros Fault Zone with thrust faulting (USGS, 2012; CEDIM, 2012).

In the city of Van, which has been affected severely by the two consecutive Van earthquakes and their aftershocks, the damage survey of structures has been generally carried out by researchers (Guney, 2012; Bayraktar et al., 2012; Baran et al., 2012; Okuyucu et al., 2012). However, in this study, only the masonry buildings in Hacibekir district, which is one of the regions including the highest density of different types of masonry buildings, are investigated in detail. This district is a suburb of the city where poor or low-income people live and is located approximately $5-6 \mathrm{~km}$ from the downtown area, as seen in Fig. 8. The majority of masonry buildings in this region were $10-15 \mathrm{yr}$ old; therefore, it may be assumed that they were built after 1990. According to this time period, in order to better understand the seismic performance of the masonry buildings, three versions of Turkish seismic codes published in 1975, 1998 and finally in 2007 (TEC, 1975, 1998, 2007) are considered to review. It is clear

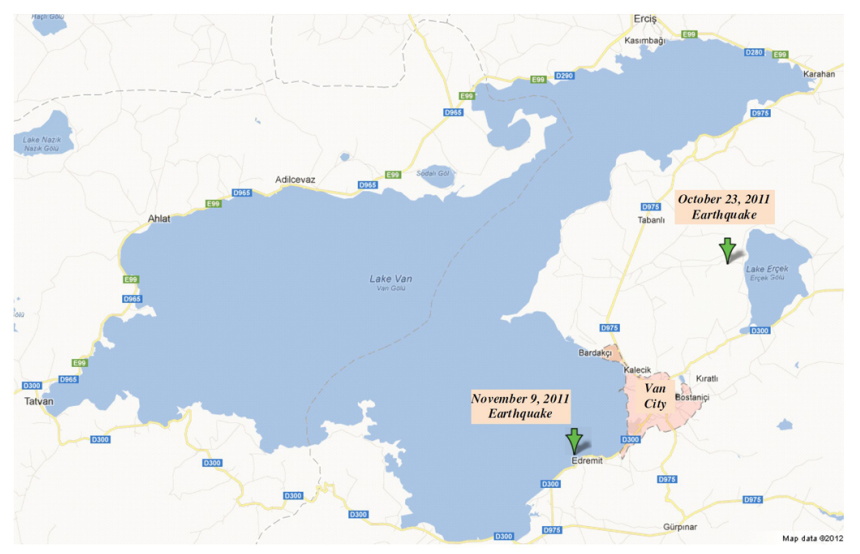

Fig. 2. Locations of the two consecutive Van earthquakes, 2011 (USGS, 2012).

that all the regulations and requirements of these codes represent engineering experience and practice obtained from the last major earthquakes that occurred worldwide.

The Turkish Earthquake Code 2007 (TEC, 2007) is similar to the code published in 1998 (TEC, 1998) but very sophisticated compared with the code of 1975 (TEC, 1975) because it includes design calculations for the analysis of the masonry buildings for lateral earthquake loads, and considers allowable stress limits depending on the masonry unit and mortar used for the load-bearing walls as well as regarding the slenderness ratio of the wall (TEC, 2007).

After the two Van earthquakes the media was informed that in total 44164 temporary tents, which were supposed to be suitable only for moderate climate conditions, were distributed to the affected people. Only 34728 of them were provided by the Turkish Red Crescent (AFAD, 2012). However, the long-lasting winter conditions are always very heavy in this eastern province, with very cold and icy days, snowfalls and storms. Only the people whose buildings were totally collapsed were allowed to live in 2385 temporary healthy housing units. Therefore, the Turkish Housing Development Administration (TOKI, 2012) immediately planned an urban renewal project for Van city as well as its villages. This transformation includes 15323 permanent houses, 25 schools, 24 mosques and 11 business centers according to the records of local government (The Governorship of Van, 2012).

All the masonry buildings in this area can be classified into three different types in terms of materials and forms of construction - namely adobe buildings, unreinforced masonry buildings and confined masonry buildings, as given in Fig. 9. 


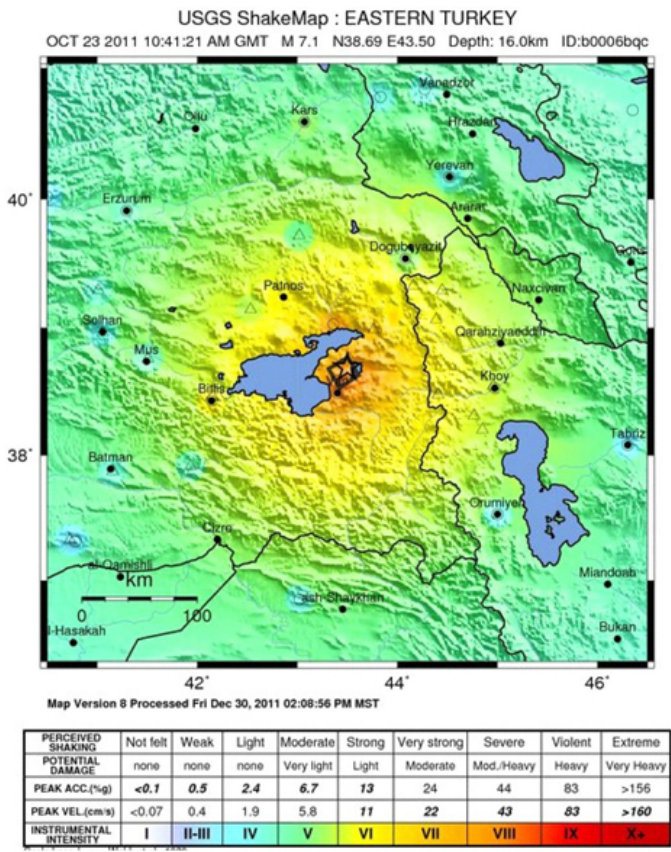

a. ShakeMap

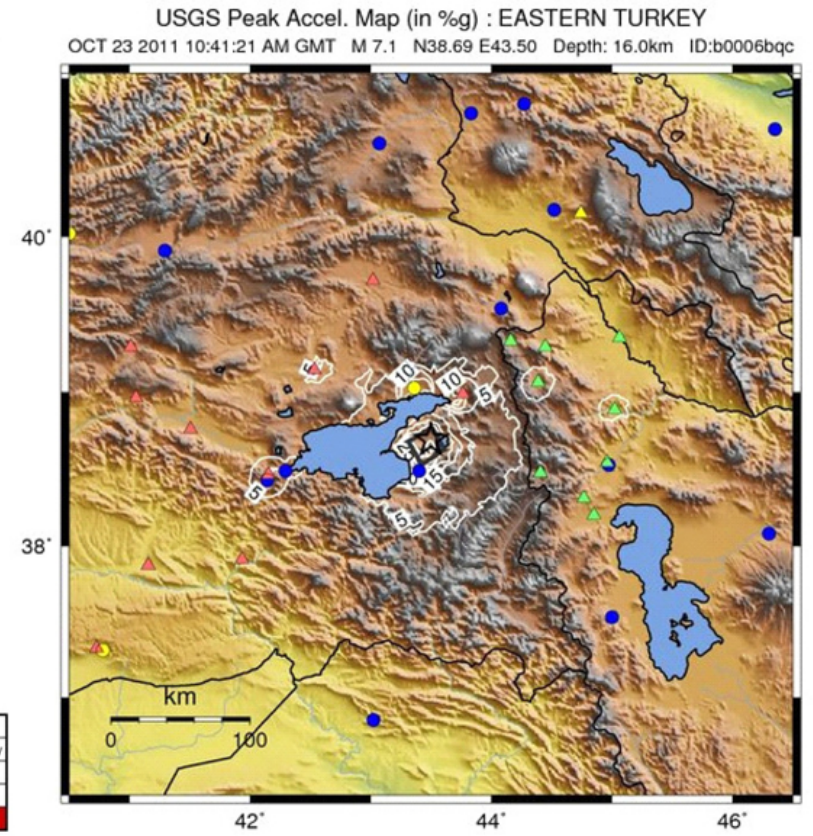

b. Distribution of the peak ground acceleration

Fig. 3. The ground motion maps of the 23 October 2011 Van earthquake (USGS, 2012).

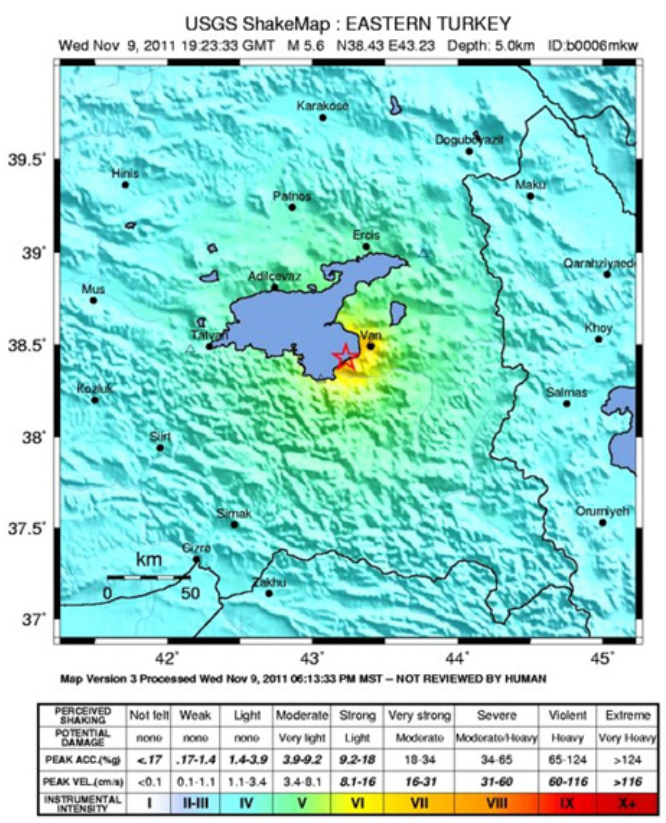

a. ShakeMap

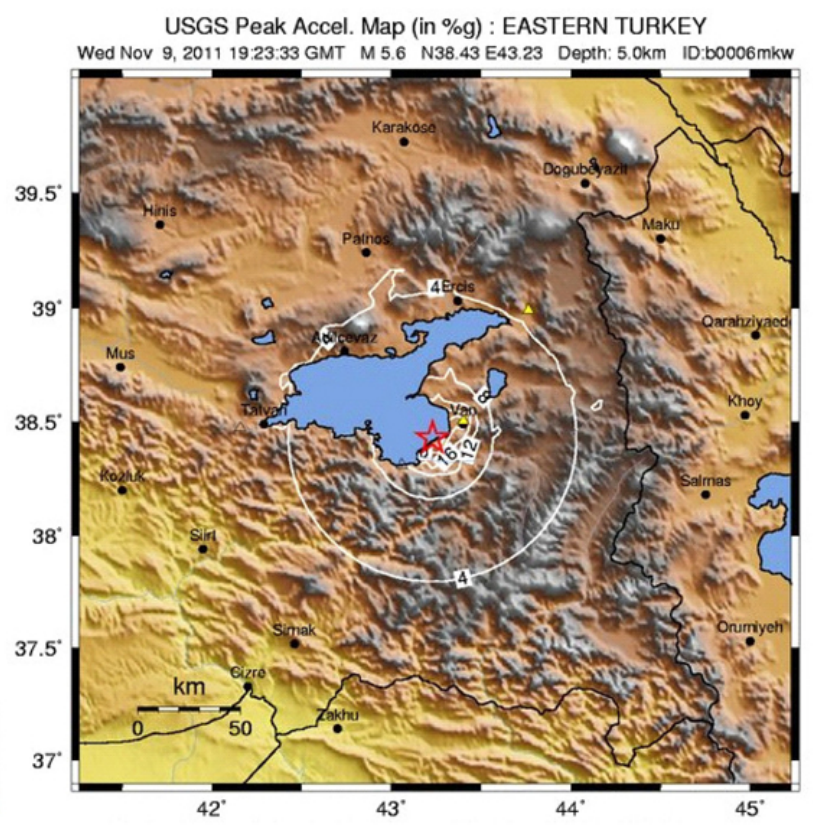

b. Distribution of the peak ground acceleration

Fig. 4. The ground motion maps of the 9 November 2011 Van earthquake (USGS, 2012).

\section{Damage investigation of the adobe and unreinforced masonry buildings}

Adobe and unreinforced masonry structures are the most popular buildings, and are especially constructed in rural areas of Turkey and also in suburbs of cities where poor or low-income people live. They can be categorized as nonengineered buildings because these buildings were traditionally constructed by homeowners or construction workers using poor construction techniques and without getting any technical expertise or following any regulations and 


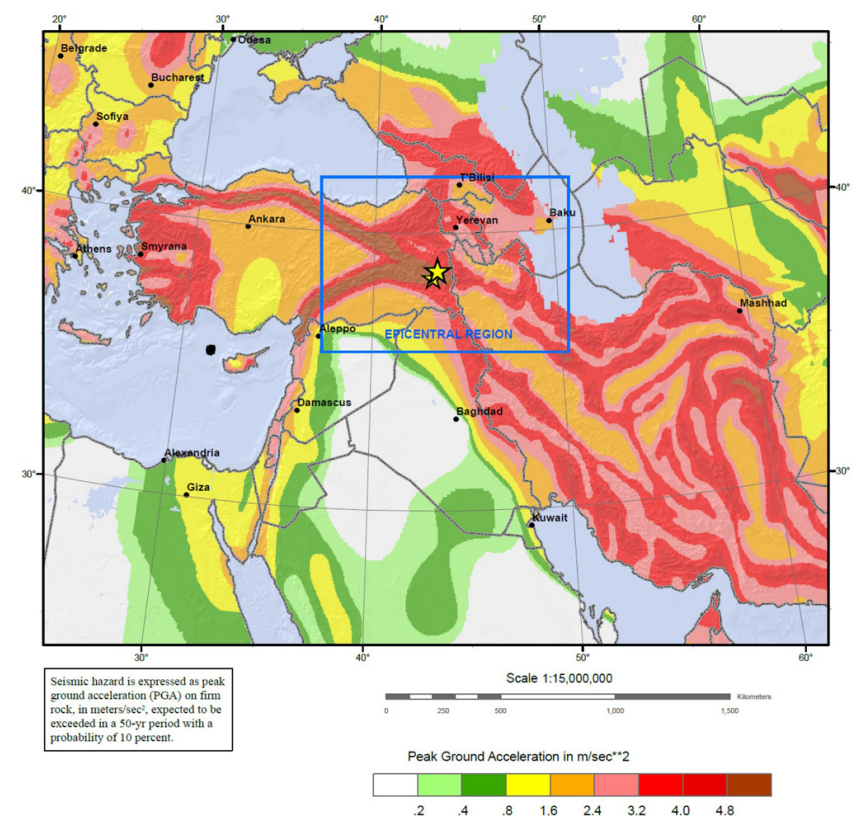

Fig. 5. The seismic hazard map of Turkey (USGS, 2012).

requirements of the current earthquake codes and relevant standards. In these buildings the vertical loads are directly transferred by the bearing walls from the roof and the floors to the foundations. However, under the horizontal seismic forces, the bearing walls are additionally subjected to in- and out-of-plane bending effects and in-plane shear effects. Depending on the brittle behaviour of the bearing walls, due to their low shear and flexural strengths, these types of buildings are highly susceptible to severe damages and total or partial collapse when they are especially subjected to lateral forces caused by the destructive earthquake waves (Bruneau, 1994; Bruneau and Yoshimura, 1996; Klingner, 2006). To enhance the earthquake performance of these unreinforced masonry buildings, horizontal band beams should be built continuously at the plinth, lintel and roof levels (Klingner, 2006; Furukawa and Ohta, 2009).

Considering a load-bearing masonry wall, in-plane horizontal seismic loads induced by a strong ground motion are diagonally transmitted to this wall from its upper to lower level. If the principal tensile stress on the masonry units exceed their tensile strength, diagonal shear cracks occur within these units (Furukawa and Ohta, 2009). Should the strength of the masonry unit be relatively stronger than the mortar strength, developed cracks follow in a zigzag path along the mortar joints (Furukawa and Ohta, 2009). When the compressive strength of the masonry units is exceeded by their principal compressive stresses, crushing is formed at these units (Furukawa and Ohta, 2009). The crushings and the diagonal cracks passing through them cause lack of stability of the bearing wall and lead to its failure.
The adobe and unreinforced masonry buildings in Hacibekir district were mainly one-story residential buildings discrete from the surrounding buildings and traditionally constructed up to 1990 by using neither technical expertise nor following any requirements given in the current compulsory Turkish earthquake codes (TEC, 1975, 1998, 2007) and the related design standards, as well as with a very low quality of local workmanship, as seen in Fig. 10. In unreinforced masonry buildings, load-bearing walls were typically and prevalently laid by using hollow concrete briquettes as masonry units, which are not permitted in these seismic codes. These units were mostly bonded with cement or lime mortar. Additionally, for the adobe wall constructions, claymud solid units dried by sun heat were used as a bearing material and the integrity of the wall was provided by using clay or mud mortar. The use of different masonry wall materials for the same wall was not observed. The interior and exterior surfaces of the walls were mostly covered with lime plaster of approximately $5 \mathrm{~cm}$ thickness. In some of the adobe buildings, the thickness of the bearing walls was measured as $40-50 \mathrm{~cm}$. The thickness, the slenderness ratio, the unsupported plan length of a wall as well as its connection details are the main parameters which control its out-of-plane flexural strength (Bruneau, 1994; Klingner, 2006). If the walls and floors are not properly connected, supported or anchored, overturning moments can cause gaps along the height of these walls or even collapse of them (Bruneau, 1994).

In these buildings the roofs which are expected to act as a diaphragm were constructed as traditional heavy, flat roof systems by using thick mud or earth layers supported on wooden logs, as given in Figs. 11 and 12. The wooden log ends were directly supported on the width of the walls along their lengths without using any type of connections. And, to improve the seismic resistance of the bearing walls and also to provide the distribution of the loads acting on the masonry walls, it was observed that the roof band beams were not built at the roof level on top of the walls. The logs were typically sheathed with timber planks nailed perpendicular to the direction of the logs. The timber sheathing was also plastered by a thick mud layer made of straw and clay. These heavy roof systems are vulnerable to strong ground motions which cause larger seismic forces as well as larger lateral displacements; however, it is noticeable that the increased friction resistance due to the weight of the roof can cause higher strength for these structures than expected (Furukawa and Ohta, 2009). It was observed that strong inertia forces developed due to the two Van earthquakes and their strong aftershocks were the main reason for the severely damaged and partially collapsed masonry buildings in this district. According to seismic codes (TEC, 1975, 1998, 2007), in adobe buildings, soil roofs should not be constructed in the first as well as in the second seismic zones. However, especially the poor or low income people have preferred these heavy-roofed structures because they keep warm during cold winter days as well as cool during the hot summer days. 


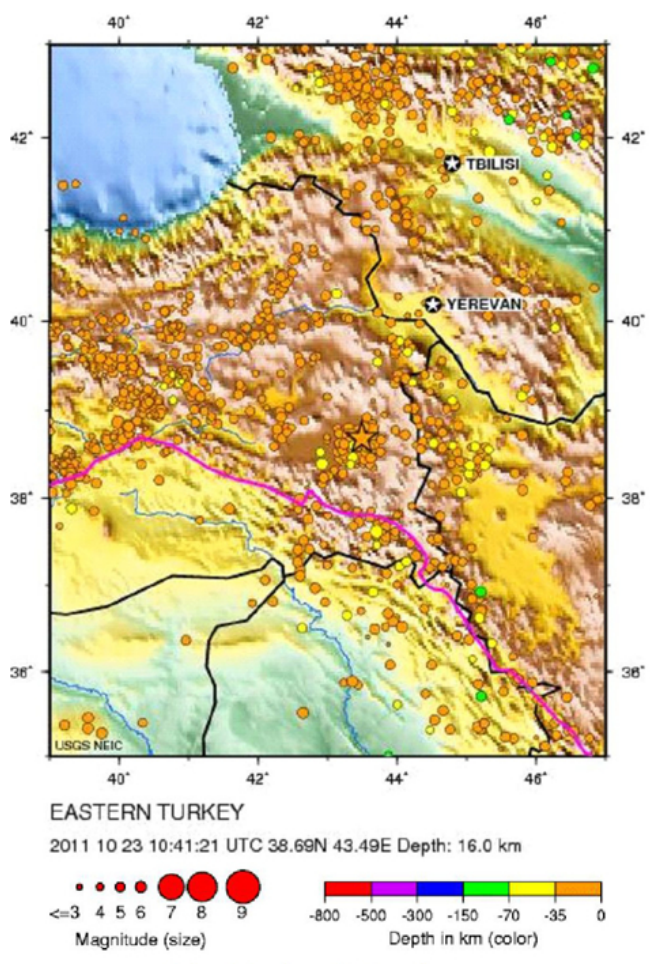

a. Se ismicity since 1990 to the present

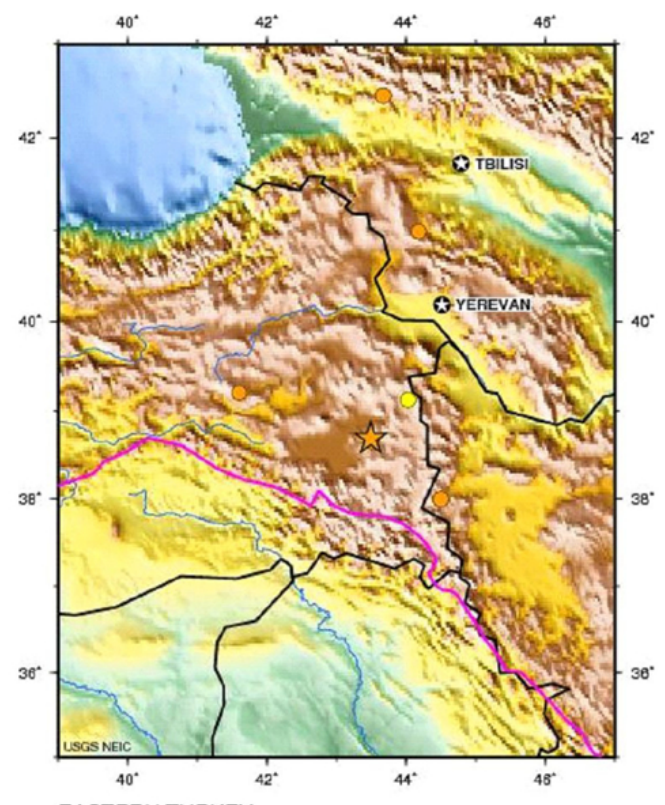

EASTERN TURKEY

20111023 10:41:21 UTC 33.69N 43.49E Depth: $16.0 \mathrm{~km}$

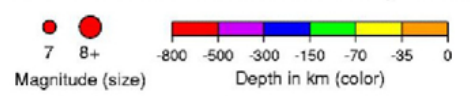

b. Magnitude 7 and greater earthquake since 1900 to the present

Fig. 6. The historical seismicity of the Van region (USGS, 2012).

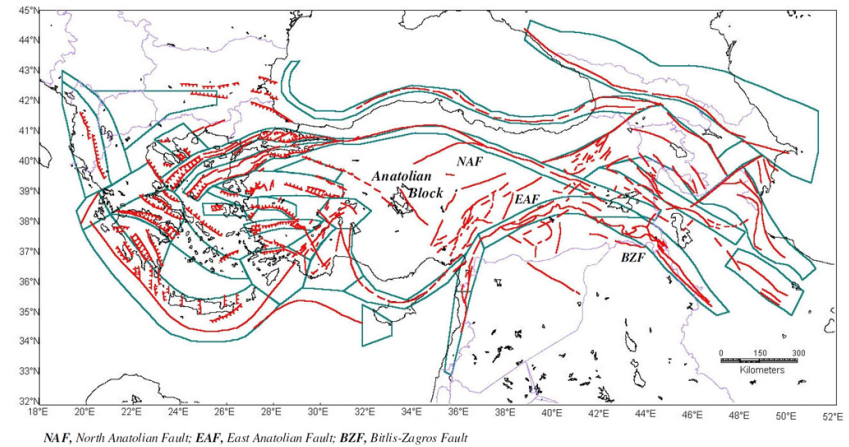

Fig. 7. The seismic source zones of Turkey (USGS, 2012; GSHAP, 2012).

The foundations of these buildings were mostly constructed at about $30 \mathrm{~cm}$ to $50 \mathrm{~cm}$ depths directly on the ground surface, as shown in Figs. 12 and 13, and the masonry walls were apparently built without using any plinth band beams and proper connections or anchorages on the top of the foundation. The plinth band beams should be built to prevent settlement of the building and also to provide lateral resistance and integrity to these buildings (Furukawa and Ohta, 2009). The foundations were generally laid in courses formed by intermingling of stones having non-uniform sizes and shapes and sometimes without using any mortar.

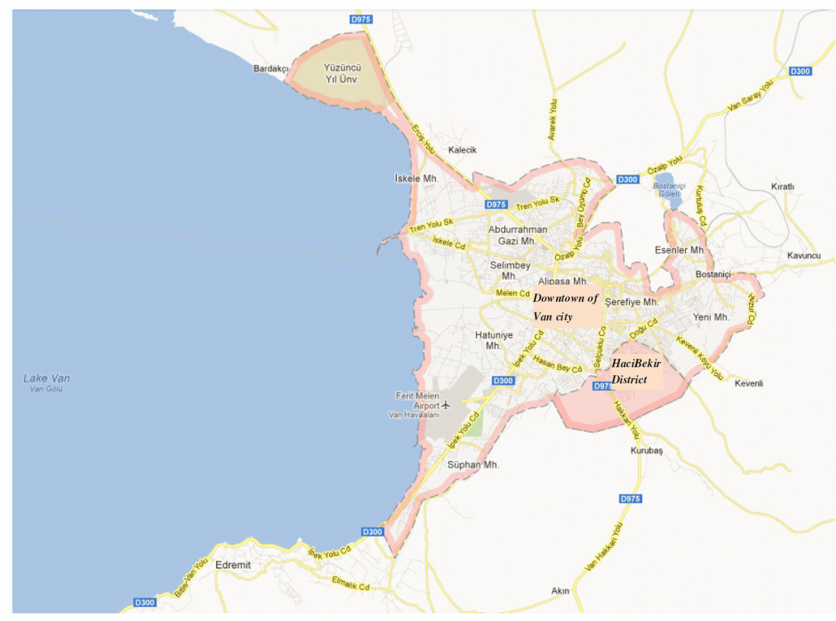

Fig. 8. Locations of Van city and the Hacibekir district.

Because of the lack of the horizontal band beams, which should provide structural integrity and the adequate connections between the bearing walls at the wall intersections and between the bearing walls and the roof, each wall acts individually in in-plane as well as out-of-plane directions under the earthquake loads (Bruneau, 1994; Bruneau and Yoshimura, 1996; Furukawa and Ohta, 2009). Due to this inadequacy, it was observed that severe vertical cracks and gaps 


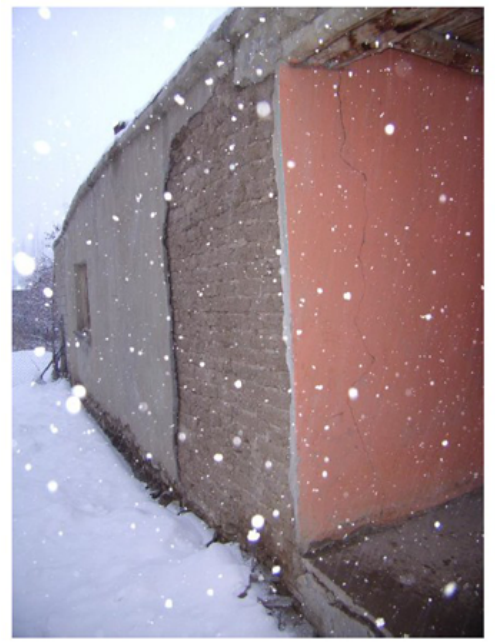

a. Adobe building

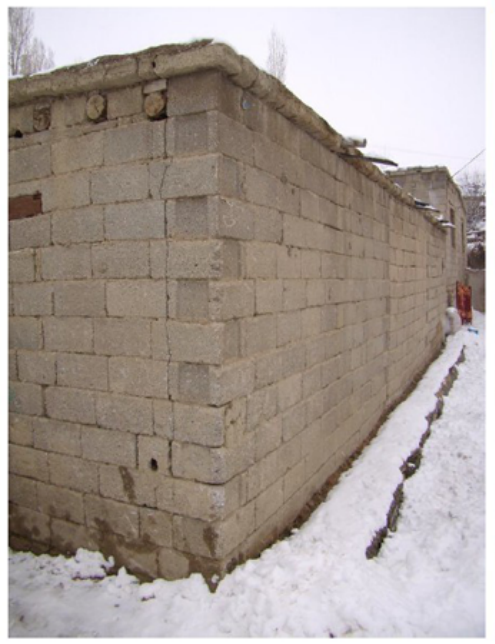

b. Unreinforced masonry building

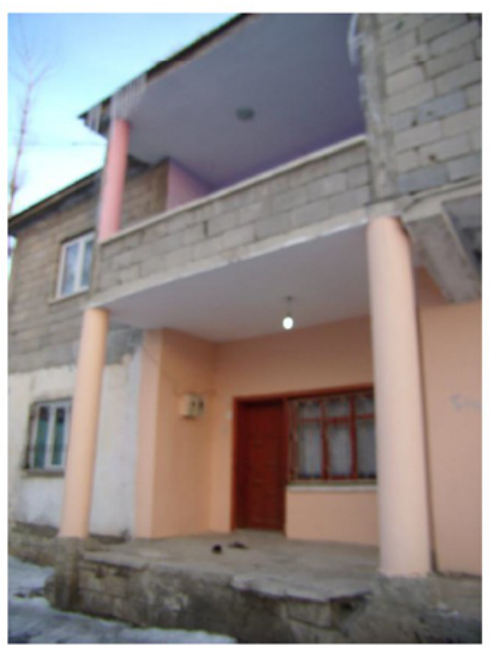

c. Confined masonry building

Fig. 9. Types of the masonry buildings.

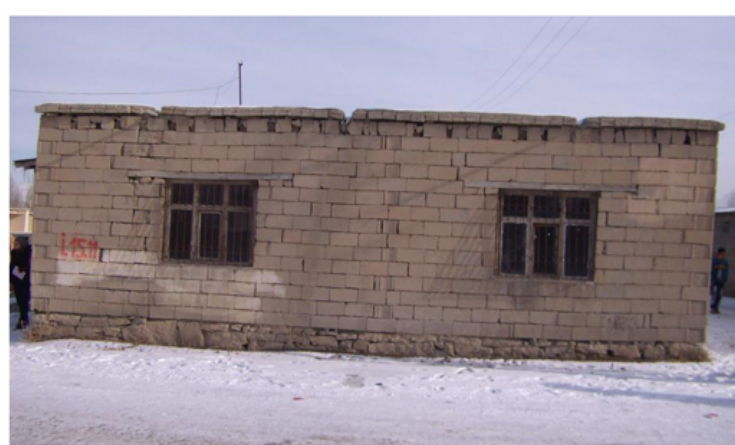

a. Front view of a dwelling

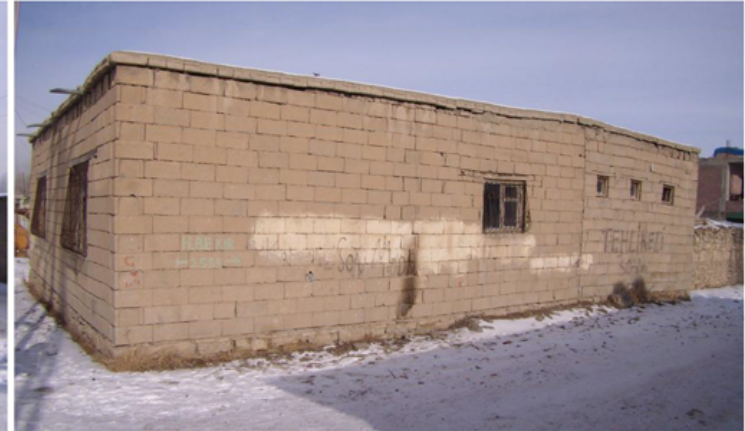

b. Side view of a dwelling

Fig. 10. Outside views of a typical unreinforced masonry building.

had frequently developed and propagated along the height of the bearing wall intersections, as seen in Figs. 14 and 15. Gaps of up to $10 \mathrm{~cm}$ were measured at the top of these walls due to the lack or inadequate anchorage of the wall-to-wall connections.

The most common damage observed in the unconfined masonry buildings was the inclined cracks that developed at the bearing wall portions above and below the window openings and above the door openings. It was observed that the cracks propagated from the corners of the openings where high stress concentrations exist occurred due to the lack of lintel and sill beams which should be constructed above and below the openings in the bearing walls, as seen in Figs. 16 and 17. Timber beams were mostly used as the lintel-beams for the door and window openings of the masonry walls in the Hacibekir district as well as in rural areas of Turkey.

Furthermore, confining tie columns constructed on both sides of these openings could also prevent the propagation of the inclined cracks in this part of the bearing wall, as recommended in Turkish earthquake codes (TEC, 1998, 2007). Additionally, these tie columns should improve the stability of these walls by the means of their slenderness ratios.

The wooden logs supported on the masonry walls led to plaster spalling and vertical cracks starting under the log ends and developing along the top of the wall because of the compressive stresses. It is clear that due to this, a decrease or even loss of strength of the bearing wall can be expected, as seen in Figs. 17 and 18. During the field study, it was observed that some of the logs were previously weakened by the severe cracks naturally occurred along their lengths during their lifetime (see Fig. 18). Sometimes it was seen that the exterior or interior plaster was partially or totally spalled along the adobe walls and gaps had developed at the intersection of the bearing walls, as seen in Figs. 19 and 20. It is possible to expect that these walls should collapse due to the effects of the strong future aftershocks. Based on the field observations, heavy flat roofs of the adobe buildings supported 


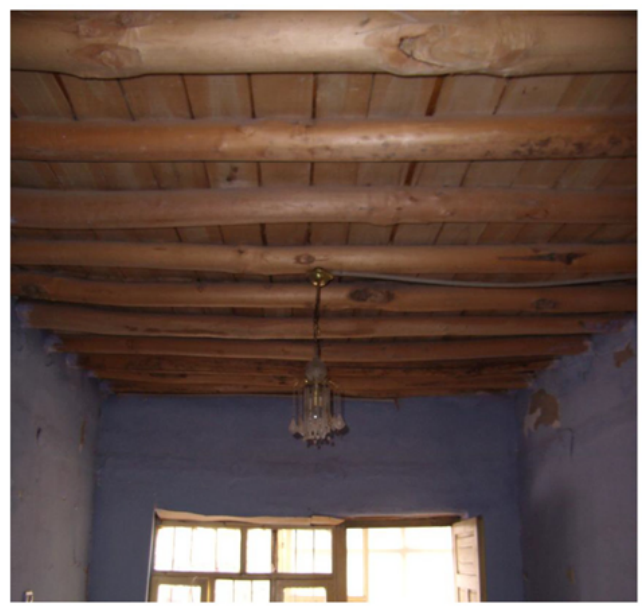

a. Front view of a dwelling

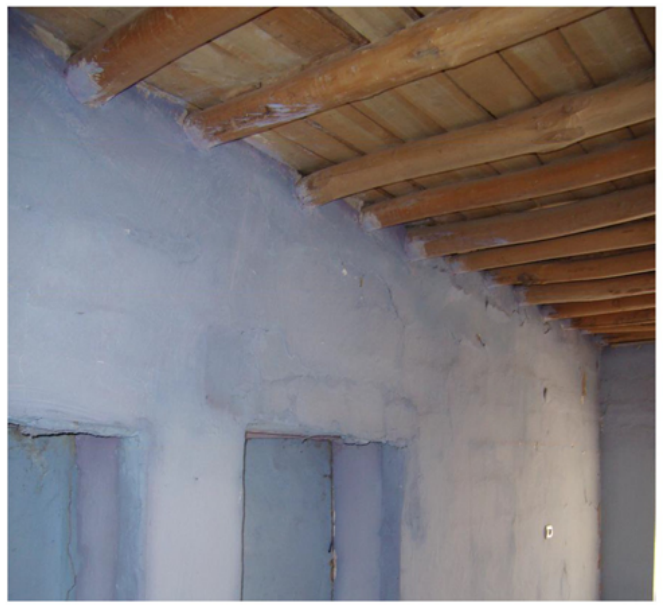

b. Side view of a dwelling

Fig. 11. Views from the interior of the traditional roof system with wooden sheathing.

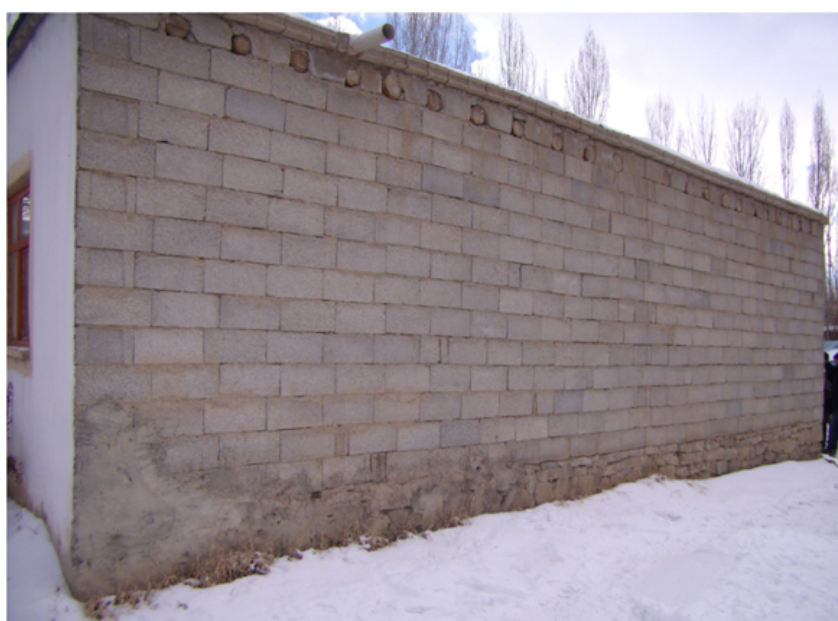

a. Location of the wooden $\log$ ends on the tops of the wall

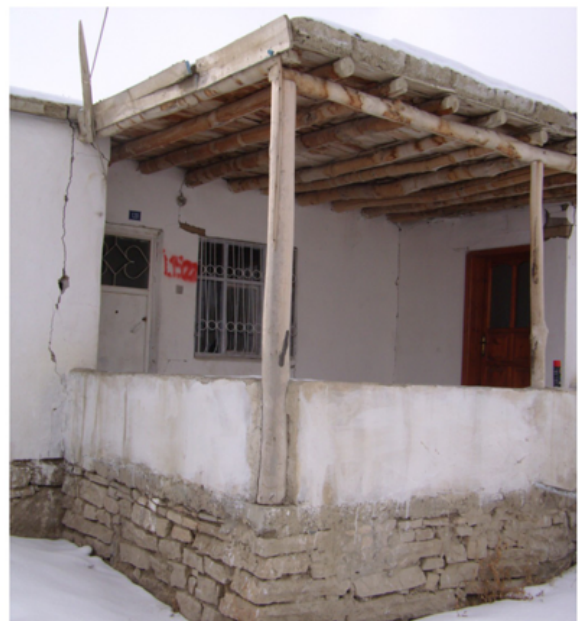

b. View of a thick flat roof

Fig. 12. Outside views of a traditional roof system.

by wooden logs were severely affected by the earthquakeinduced inertia forces due to their weight, and as a result of this roofs and bearing walls had partially collapsed. To prevent the total collapse of these roofs, the logs were supported by using wooden posts, as seen in Fig. 21. Occasionally, the debris of the partially collapsed buildings was removed by the homeowners, as shown in Fig. 22.

As mentioned before, to transfer the seismic loads through the walls to the foundation, the absence of horizontal band beams at plinth, lintel and roof levels plays an important role. Using flexible slabs reduces diaphragm behavior so that the earthquake induced lateral loads cannot be uniformly distributed regarding the bearing wall rigidities. Poor wall-towall as well as wall-to-floor connections prevent box-like behaviour of the masonry buildings. As a result of all of these factors, some restrictions are given for the number of stories and basements in Turkish earthquake code. However, using vertical tie columns enhances shear and flexural strengths of the load-bearing walls, so it is possible to construct more stories in seismic vulnerable zones according to the Turkish earthquake code.

In the Turkish seismic codes (TEC, 1998, 2007), detailed information for the materials and their permitted thicknesses are given. The concrete briquettes with holes, and light aggregated concrete masonry units are strictly forbidden to use (TEC, 1975, 1998, 2007). Additionally, all the bricks and block bricks with holes which do not fulfill the maximum hollow ratio given for the holes in the Turkish design standards (TS2510, 1977; TS705, 1985; TS EN 7711, 2011) are not allowed to be used (TEC, 1998, 2007). 


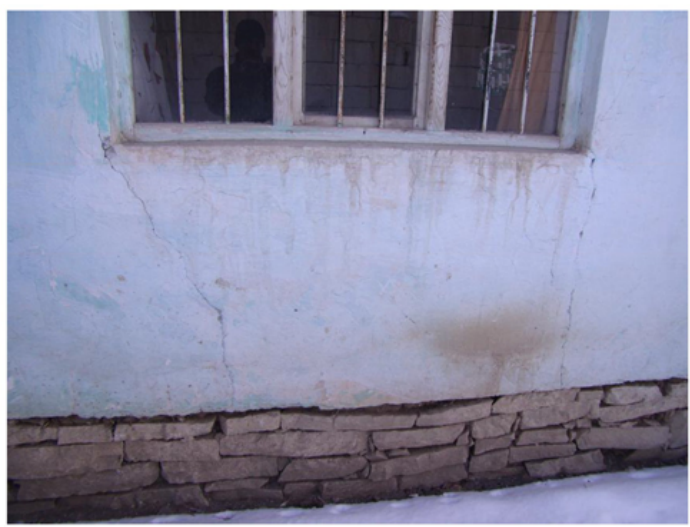

a

Fig. 13. Views for the typical foundation of a masonry building.

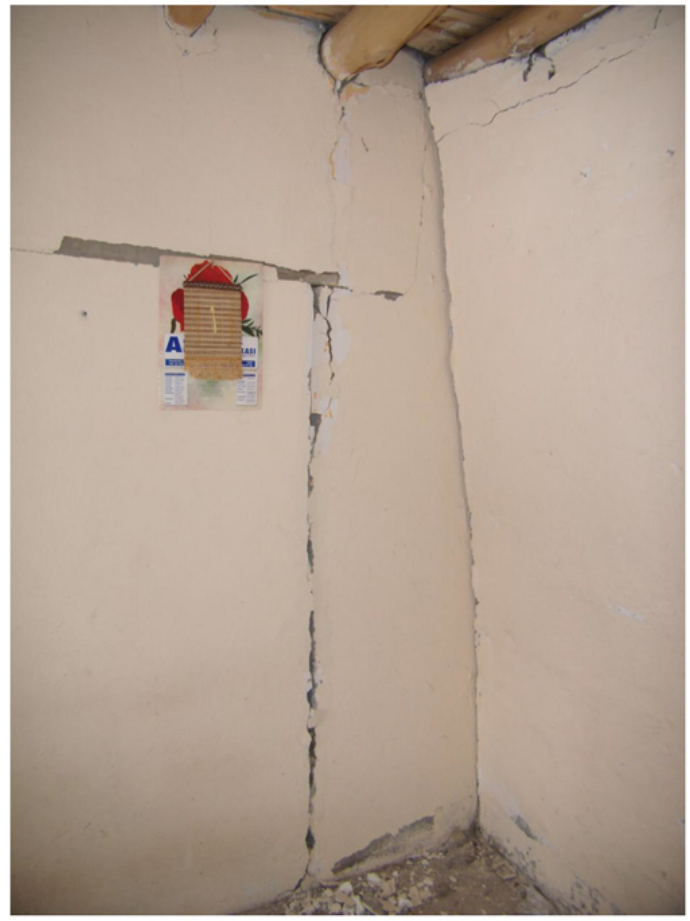

a

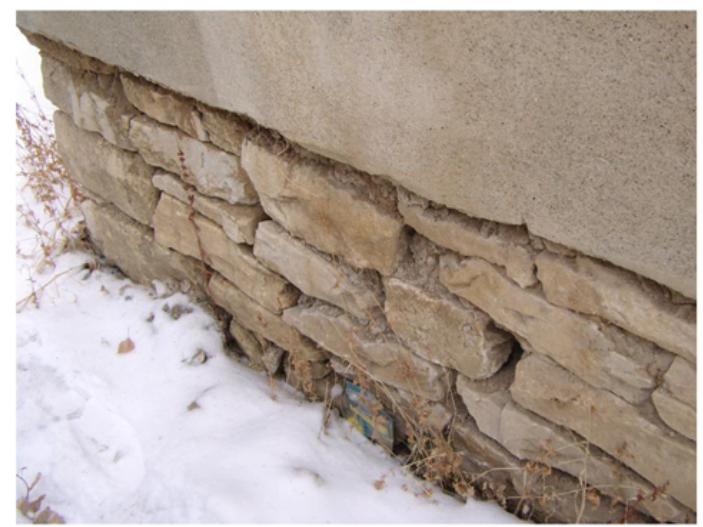

b

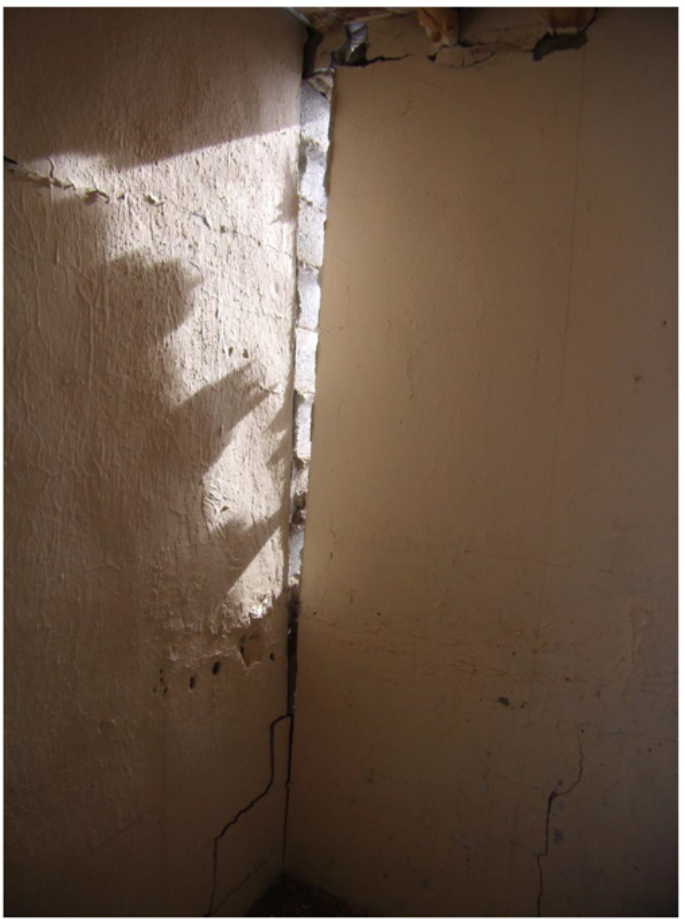

b

Fig. 14. Severe damages due to overturning moments and developed gaps at the intersections of the bearing walls.

Furthermore, the minimum compressive strength of the loadbearing wall materials should be at least $5 \mathrm{MPa}$ (TEC, 1975, 1998, 2007). The mortars enhanced with cement should be used for load-bearing walls, with the volumetric ratio defined as cement/lime/sand $=1: 2: 9$ or cement mortar as cement/sand $=1: 4$. Based on these requirements of the earthquake resistant design rules, a maximum of 2 stories including the basement are only permitted for masonry buildings with bearing walls in the first seismic zones, and 3 stories in the second and third seismic zones in Turkey. In adobe buildings only one single story without any basement is allowed for all seismic zones.

The story heights of the masonry buildings are defined as maximum $3 \mathrm{~m}$ for the load-bearing walls and $2.7 \mathrm{~m}$ for the adobe walls (TEC, 1975, 1998, 2007). If a basement is present in an adobe building, then a maximum of $2.4 \mathrm{~m}$ is allowed for the story height (TEC, 1998, 2007). Depending on the field survey conducted in Hacibekir district, it can be said that there was no problem with these permitted upper limit values for the story heights. From a structural viewpoint, 


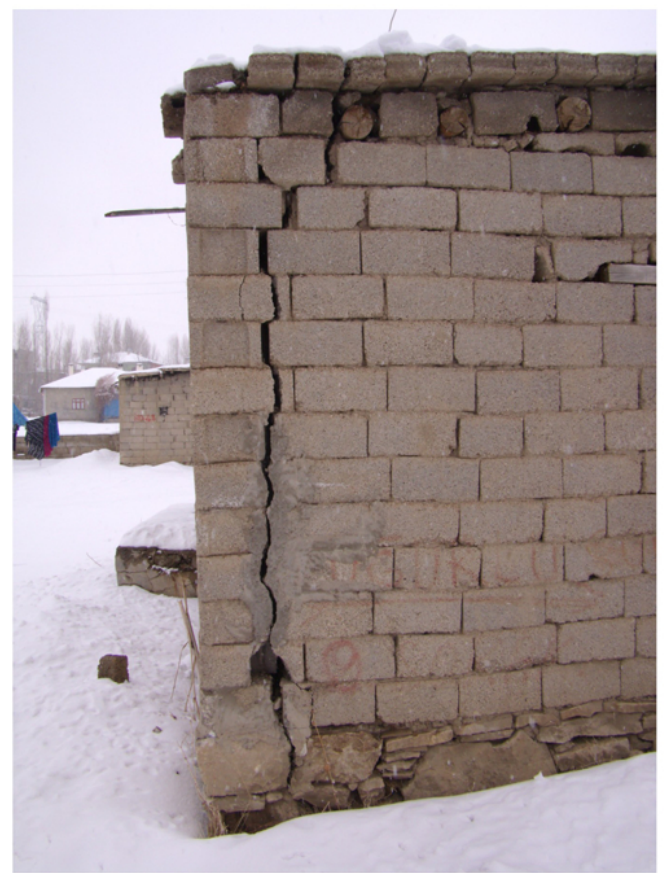

a

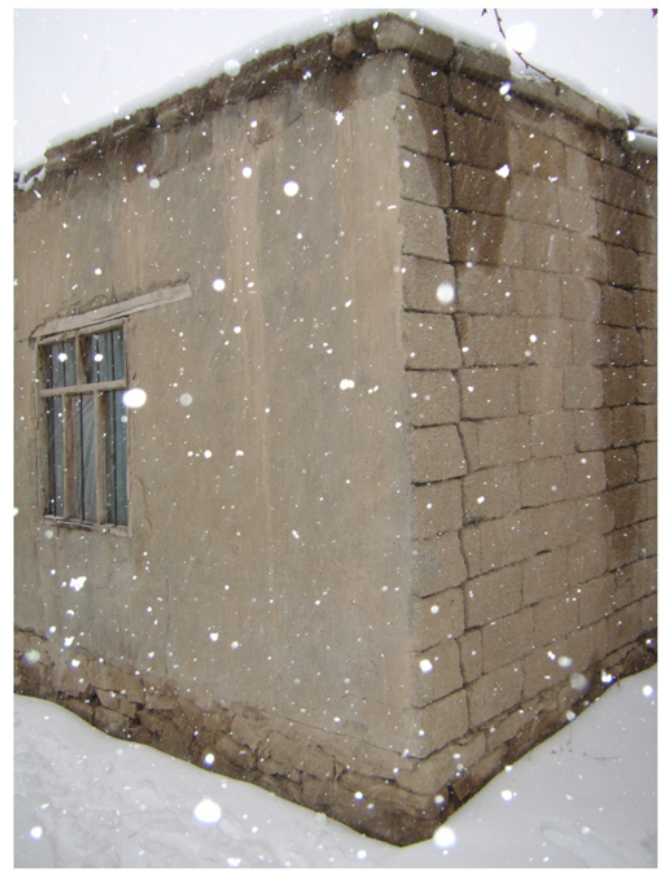

c

Fig. 15. Serious vertical crack propagations in the walls.

another requirement is defined for the arrangements of the bearing walls in plan. It is recommended to arrange these walls regularly and symmetrically or nearly symmetrically with respect to the main axes in order to prevent development of torsional moments and cracks (Klingner, 2006), as seen in

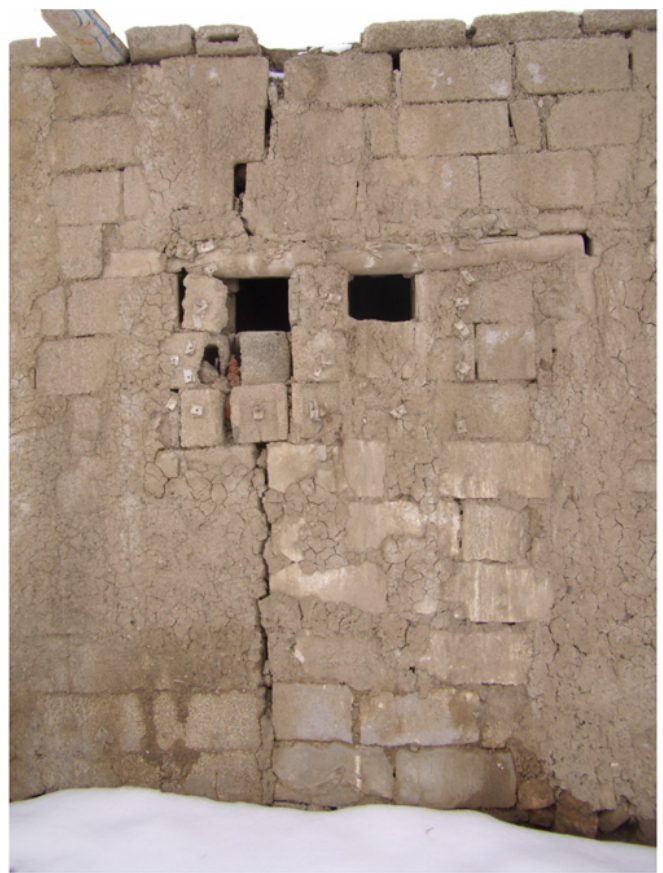

b

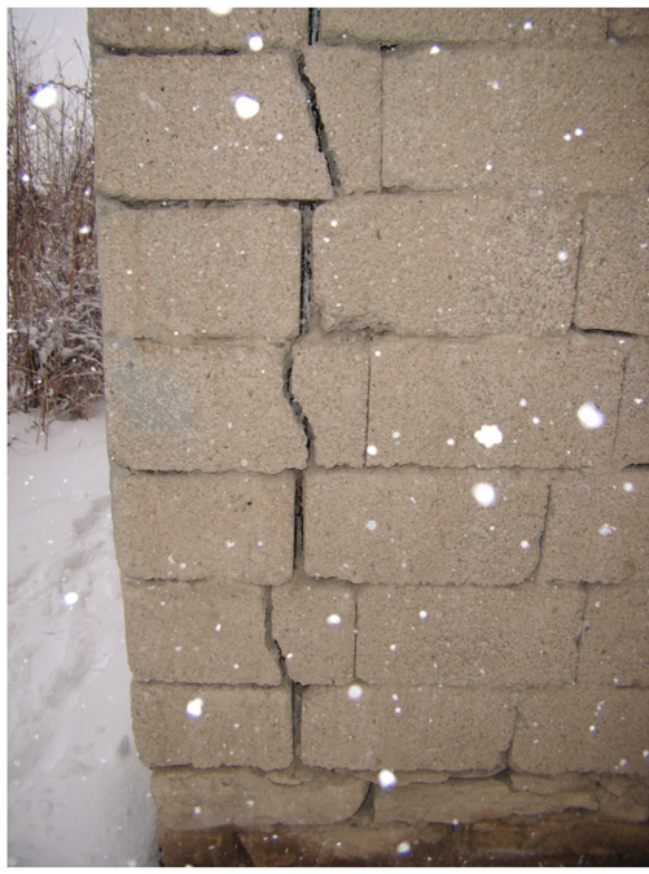

d

Fig. 23. In the field it was mostly observed that symmetry of the buildings was mainly present in one direction, but in the other orthogonal direction this requirement was nearly satisfied. The continuity of the bearing walls in vertical direction is another important restriction of the Turkish earthquake 


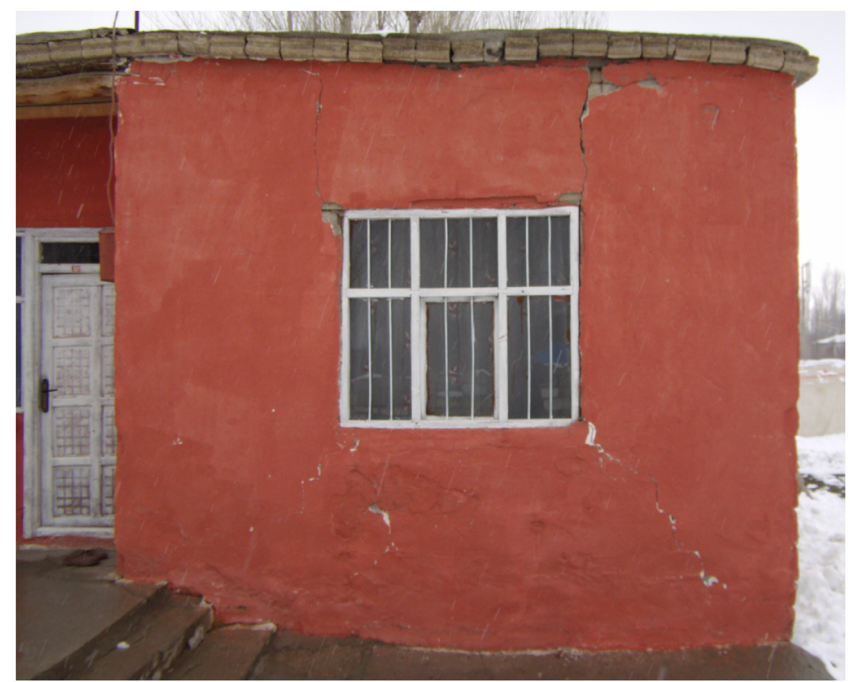

Fig. 16. The cracks developed at the sill and spandrel parts of a masonry wall with a window opening.

resistant building design codes, i.e., the load-bearing walls in the next story should be constructed so that they have to be placed one over the other. As adobe and unreinforced masonry buildings with more than one story were not observed, no problem was detected in the means of this requirement.

In Turkish seismic codes (TEC, 1975, 1998, 2007), the foundations of masonry buildings are defined as a continuously constructed reinforced concrete underwall built just under the bearing walls. Concrete quality is defined as at least C16. Soil characteristics have to be considered by designing this concrete underwall and its rebars. Additionally, local frost depths and the groundwater levels are also required in order to design its depth. Thus, for the soil type of highest strength, minimum thickness of an underwall should be $50 \mathrm{~cm}$ plus $15 \mathrm{~cm}$ on both sides, where at least $50 \mathrm{~cm}$ is required for its height. The values defined for lower strength are higher than these limits. For the reinforcement, 6 longitudinal rebars of at least $12 \mathrm{~mm}$ diameter with the hoops of at least $8 \mathrm{~mm}$ (TEC, 1998, 2007) and $6 \mathrm{~mm}$ (TEC, 1975) diameters with at most $30 \mathrm{~cm}$ spacings should be used as a code requirement. Additionally, if no basement exists in a masonry building then the top level of the stone or concrete walls constructed just on the concrete underwall should be higher than the pavement level, where at least $50 \mathrm{~cm}$ is required (TEC, 1998, 2007).

In masonry buildings the unsupported plan length of a bearing wall plays a crucial role on its shear and flexural strengths. For the unsupported length of any load-bearing wall between the bearing wall axes in perpendicular direction of the building plan, the upper limit value is given as $5.5 \mathrm{~m}$ for the first seismic zone (TEC, 1975, 1998, 2007) and $7.0 \mathrm{~m}$ (TEC, 1975) or even $7.5 \mathrm{~m}$ (TEC, 1998, 2007) for the other seismic zones. For adobe walls, this value is stated as $4.5 \mathrm{~m}$

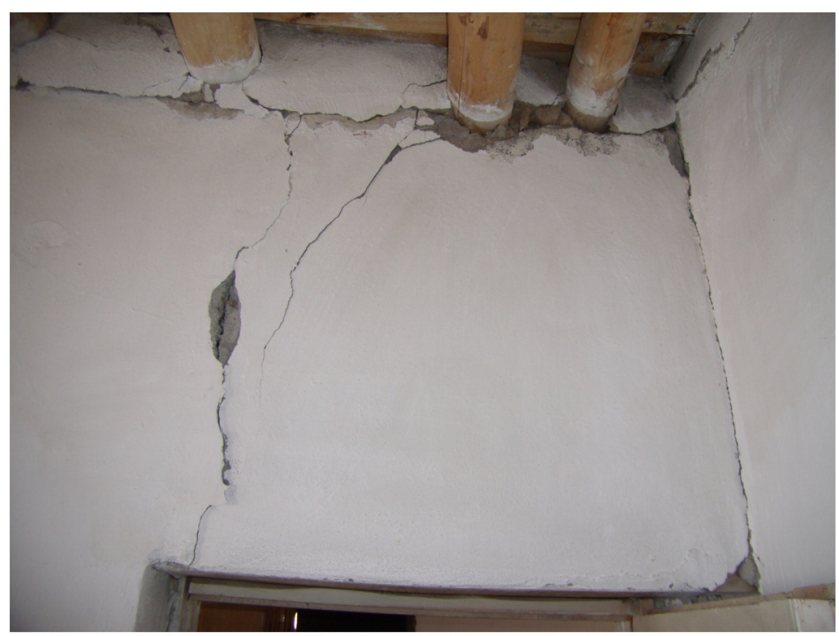

Fig. 17. Plaster spalling and the cracks developed at the spandrel part of a masonry wall above the door opening.

(TEC, 1975, 1998) and in recent years $4.0 \mathrm{~m}$ (TEC, 2007). It was observed that this restriction was mainly satisfied.

Excluding the corners of the masonry buildings, the plan length of a solid wall segment between the intersection of the walls and the door or window openings should not be less than $50 \mathrm{~cm}$ for all seismic zones in Turkey (TEC, 1998, 2007) and $80 \mathrm{~cm}$ for the first and second seismic zones (TEC, 1975). Depending on the site investigations, these lengths were 5 to $20 \mathrm{~cm}$ for the door openings in practice, as seen in Fig. 17. Otherwise, tie columns are recommended on both sides of the doors to decrease this length value (TEC, 1998, 2007). These structural members were not observed in any unreinforced masonry buildings although the lengths were measured shorter than this required dimension. Additionally, the upper limit value of the plan lengths of the doors and windows should be less than $3.0 \mathrm{~m}$ (TEC, 1975, 1998, 2007). In adobe walls, this limit value is defined as $1.0 \mathrm{~m}$ in horizontal and $1.9 \mathrm{~m}$ in vertical axis for the door openings, and, additionally, $0.9 \mathrm{~m}$ in horizontal and $1.2 \mathrm{~m}$ in vertical axis for the window openings. These restrictions were generally fulfilled in this region.

It was also observed that the plan lengths of the solid wall segments between the window and door openings, excluding the corners were mainly constructed more than $1.00 \mathrm{~m}$, as is permitted in the first and second seismic zones (TEC, 1998, 2007) and seen in Fig. 10. In the code (TEC, 1975), it is stated that this length should be more than $0.8 \mathrm{~m}$ and also more than $1 / 4$ of the maximum length of the openings which are on both sides of the solid wall segment. Plan length of the solid wall segments should be set more than $1.5 \mathrm{~m}$ between the corner of a building and nearest window or door openings in the first and second seismic zones (TEC, 1975, 1998, 2007). It was observed that this requirement was mainly fulfilled in most of the masonry buildings, as seen in Figs. 10, 15 and 16. 


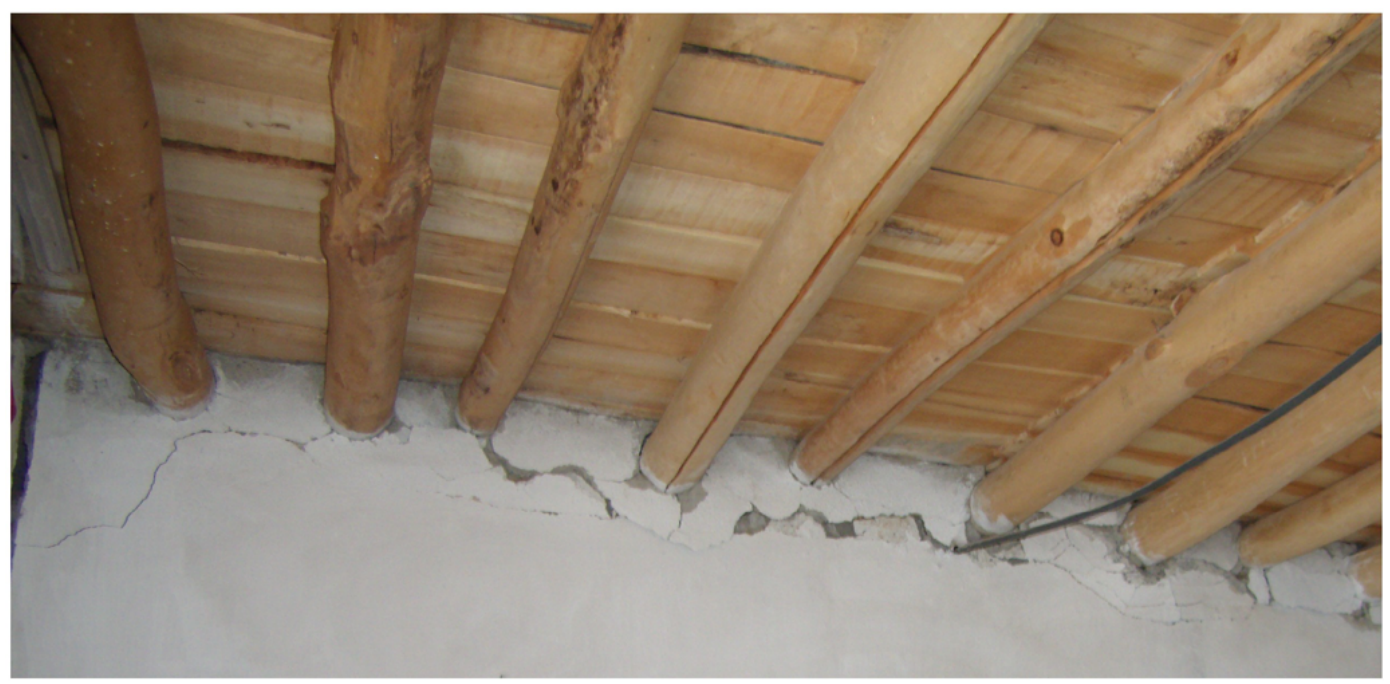

Fig. 18. The plaster spalling under the log ends and longitudinal cracks in some logs.

\section{Damage investigation of the confined masonry buildings}

In the confined masonry systems, the load-bearing masonry walls are circumscribed by using reinforced concrete members (TEC, 1975, 1998, 2007). In the Hacibekir district of Van city, the confined masonry buildings with load-bearing walls which were confined by reinforced concrete columns and beam elements were commonly built. In these buildings the horizontal and the vertical reinforced concrete elements are provided to enhance the seismic resistance of the masonry walls (Klingner, 2006; Furukawa and Ohta, 2009). If the buildings of this type are properly constructed, they can perform very well without occurrence of severe damages or collapse due to the earthquake effects (Klingner, 2006; Furukawa and Ohta, 2009). However, in this region, all these buildings were traditionally built by their owners, artisans or craftsmen without following the current rules given in the Turkish earthquake codes. Thus, these buildings which were traditionally built are called non-engineered structures. In the last two Turkish earthquake codes (TEC, 1998, 2007), the design regulations of these reinforced concrete tie columns are given in detail. According to the earlier code (TEC, 1975), a reinforced concrete moment frame is recommended to transmit the loads by also regarding the rules of the current design standard for the reinforced concrete buildings, i.e., the relevant TS500 code. This provision points out the soft story behavior of the structures if large areas are planned to cross.

The confined masonry buildings were from one to three stories, commonly two stories in height, and usually had a semi-basement and an exterior staircase, as seen in Fig. 24. These buildings commonly had pitched or hipped roofs covered by clay tiles. Exterior surfaces of the bearing walls were not generally covered with plaster. Because of the lack of the plaster, the units and the mortar may be weakened and deteriorated by the corrosive effects of the weather conditions and extreme moisture damage, and thereby the bearing capacity and strength of the walls will be inevitably reduced. It was observed that in the most of the building plans, the symmetry was present or nearly present only in one direction; in the other direction the plan was not regular from the structural point of view. The walls were mostly continuous along the height of the building, but many buildings were built with cantilever beams along the width of the front facade and, generally, the openings in the walls were perpendicularly placed in the same position. The cantilever beams were supported by tie columns. It is clear that these beams can vertically vibrate during the earthquakes, and this action may lead to additional tension stresses in the masonry units, and may result in development of diagonal cracks.

In the confined masonry buildings constructed in this region, foundations were commonly built as the coursed stone masonry footing at about 0.5 to $1.0 \mathrm{~m}$ depths. On the top of the foundations, reinforced concrete plinth band beams were constructed. Then, the masonry walls were firstly laid on the top of the plinth band beams. Afterwards, vertical reinforced concrete members called as tie columns were constructed at the wall intersections and ends. The tie columns were generally built, with the cross sections of $250 \times 250 \mathrm{~mm}$ or $300 \times 300 \mathrm{~mm}$ for the exterior columns and $200 \times 200 \mathrm{~mm}$ for the interior columns, by using four $10 \mathrm{~mm}$ diameter longitudinal steel bars and $8 \mathrm{~mm}$ diameter stirrups having spacings between 400 and $600 \mathrm{~mm}$. The width of tie columns was made equal to the wall thickness. In recent years $12-14 \mathrm{~mm}$ diameters for the rebars and $15 \mathrm{~cm}$ to $20 \mathrm{~cm}$ spacings for the stirrups have been preferred. Then, for each floor level, the reinforced concrete band beams were monolithically constructed with the floor slab on top of the walls. The crosssectional dimensions used for the band beams were approximately equal to the width of the wall and $15 \mathrm{~cm}$ or $20 \mathrm{~cm}$ in 

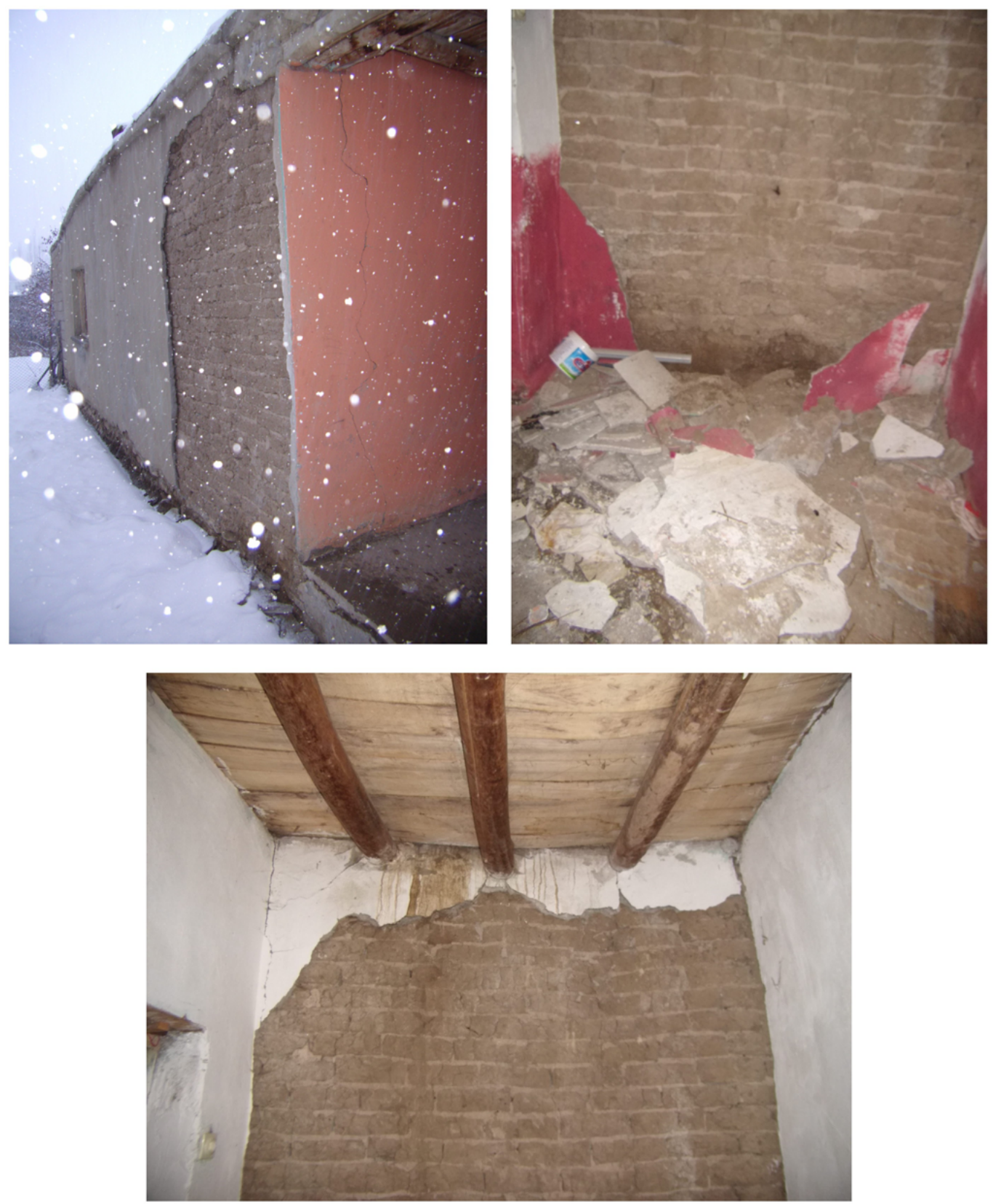

Fig. 19. The exterior and the interior plaster spalling at the adobe walls.

depth. Beam reinforcements were commonly composed of four $10 \mathrm{~mm}$ diameter longitudinal steel bars using $8 \mathrm{~mm}$ diameter stirrups, and mainly having up to $600 \mathrm{~mm}$ spacings. Concrete used in the columns and beams was mostly produced and poured with local workmanship without using any vibration technique. In some confined masonry buildings, it is noteworthy that the reinforced concrete lintel beams which were placed above the door openings were circumferentially continued along the walls of the buildings, as shown in Figs. 25 and 26. The floor slabs are monolithically constructed as reinforced concrete with the thickness equal to the beam depth.

The use of different masonry wall materials at the same floor and even at the same wall was not observed. Only in a confined two-story building, the ground floor was constructed as stone wall with a $50 \mathrm{~cm}$ thickness. The first floor with balconies was built later by using briquettes with holes. Only minor cracks on the bearing stone walls were observed where tie columns did not exist under the intersection point of horizontal band beams at lintel levels because vertical continuity plays an important role in transmitting the lateral 


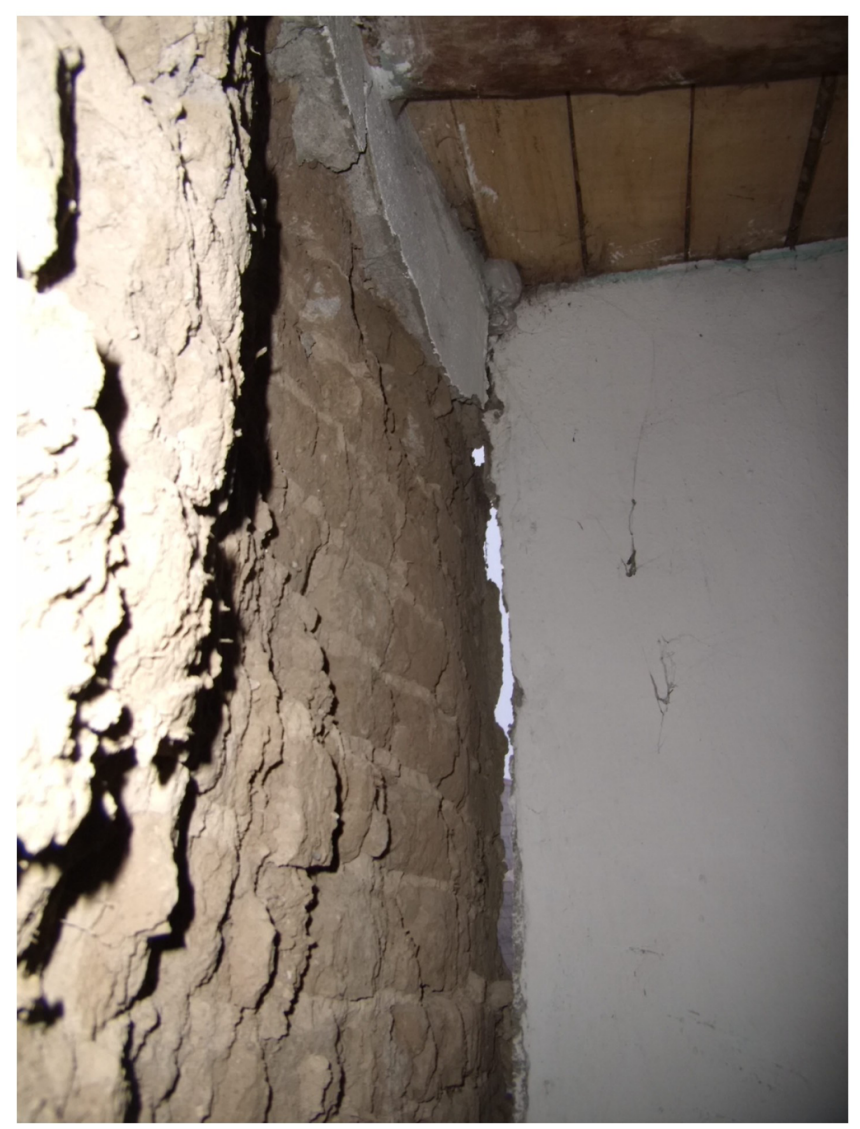

Fig. 20. The interior plaster spalling and severe separation that occurred in the intersection of the walls in an adobe building.

force. However, using different materials in different stories of masonry buildings is appropriate according to the Turkish earthquake code, but one should follow the requirements defined for sizes of wall units that will be used in ground floors and other stories above in masonry buildings.

Based on the site investigations, the confined masonry buildings in this region had usually shown good performance during the two consecutive earthquakes. The large number of these buildings only suffered minor crack damages, particularly between the masonry walls and the confining members, at the spandrel or sill parts and at the corners of the openings, as given in Figs. 27 and 28.

Although briquettes with holes which do not fulfill the main requirement of the Turkish seismic code were used in confined masonry buildings, only minor cracks are observed on some load-bearing walls. It is believed that if the soil conditions are not proper or low and, additionally, if the symmetry in plan exists, then the performance of the low material properties used for bearing walls does not affect too much the load-carrying capacity of the walls due to the existence of appropriate horizontal band and vertical tie beams in confined masonry buildings, even for the first and second seismic zones.
According to the Turkish earthquake codes, all the rules mentioned in the previous section are also valid for the confined masonry buildings. Additionally, maximum unsupported length of a load-bearing wall could be extended from $5.5 \mathrm{~m}$ to $15 \mathrm{~m}$ (TEC, 1975) or even to $16 \mathrm{~m}$ (TEC, 1998, 2007 ) in the first seismic zones, if tie columns could be constructed at the corners as well as in the walls each having plan lengths of no more than $4 \mathrm{~m}$. The same extension is also valid for the other seismic zones. It was observed that in some of the confined masonry buildings, the unsupported lengths of the bearing walls without any openings were measured as a maximum of 5 or $6 \mathrm{~m}$, and minor diagonal cracks were detected on these walls, as seen in Fig. 28b.

On the other hand, in the recent Turkish earthquake codes (TEC, 1998, 2007), analysis for horizontal earthquake loads is also possibly based on the spectrum and seismic behavior factor given. The spectrum coefficient is defined as 2.5 and the seismic load reduction factor is given as 2.5 in the previous code (TEC, 1998) and 2.0 in the last code (TEC, 2007), depending on the period of the first deflection mode of the building. Thus, the ductility considered in these codes (TEC, $1998,2007)$ can be interpreted as a low value, i.e., almost no displacement ductility is assumed for the masonry buildings (Bruneau, 1994).

In the last earthquake code (TEC, 2007), the analysis of the masonry walls is calculated by considering the allowable compression stresses, which depend on the mortar class and the compression strength of the wall material used and, are modified by regarding the slenderness ratio of the bearing wall. Additionally, for the shear forces due to the story torsional moments, if present, allowable shear stress formula is derived by assuming the friction coefficient as 0.5 and by considering allowable cracking stress for the wall, as well as the working stress calculated under the vertical loads. The elasticity modulus needed for the design calculations is given depending on the compressive strength of the bearing wall (TEC, 2007). In this region, because all the confined masonry buildings were constructed without using any engineering design project or expertise, the abovementioned analysis and design calculations were not performed for any of these residential structures.

According to the Turkish seismic codes (TEC, 1998, 2007), the minimum dimensions for the cross sections of the reinforced concrete tie columns should be equal to the thickness of the bearing walls intersecting. This requirement is also valid for the vertical reinforced concrete members built on both sides of the door openings, where the dimension parallel to the walls should be $20 \mathrm{~cm}$ at least. However, no tie columns on both sides of the door openings were observed. For the concrete quality, C16 is assumed as a minimum value in all three seismic codes. However, it was observed that this quality was very low due to extensive use of pouring concrete in the construction site with poor workmanship as well as without using any vibration technique. For the tie columns, four longitudinal rebars with at least $12 \mathrm{~mm}$ 

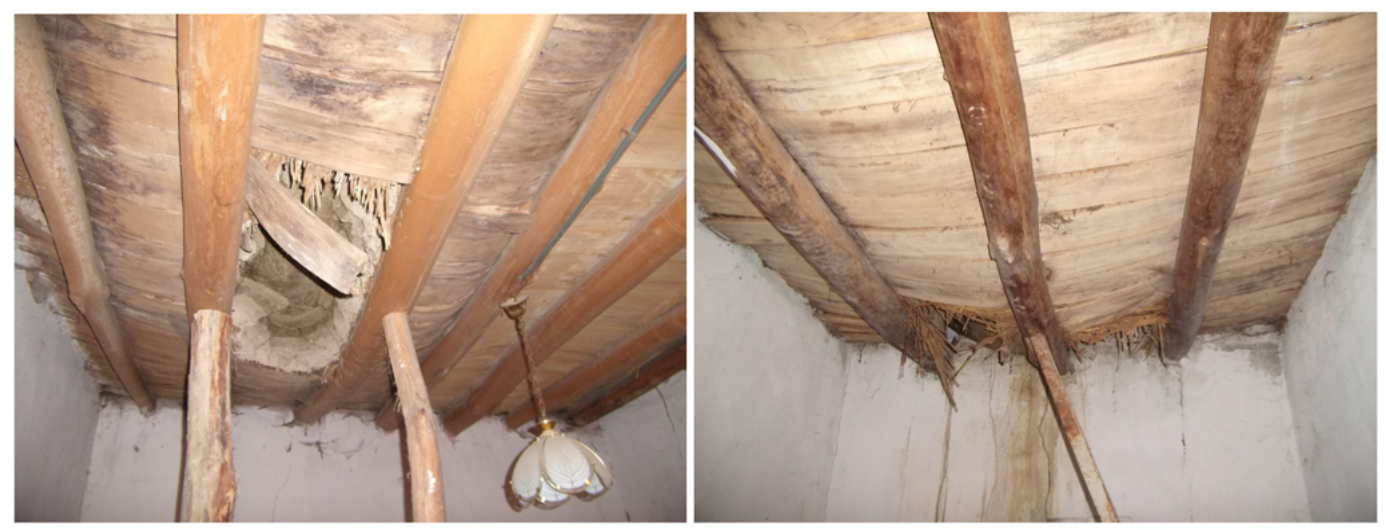

Fig. 21. Partially damages observed in a heavy flat roof system.

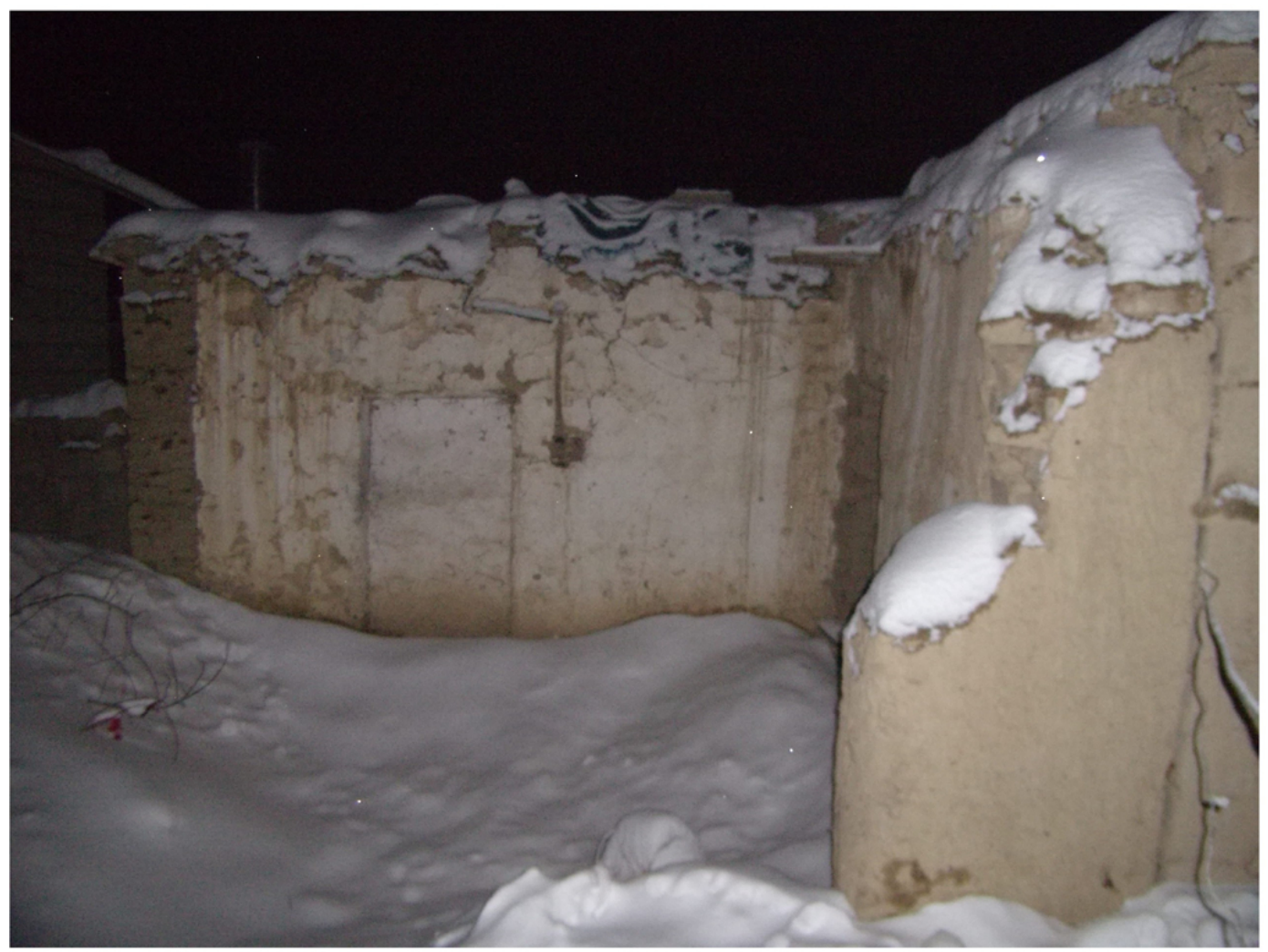

Fig. 22. A partially collapsed adobe building where the debris was removed.

in diameter are required in the last two codes (TEC, 1998; TEC, 2007), where six longitudinal rebars are defined for the stone walls by additionally using stirrups of at least $8 \mathrm{~mm}$ in diameter with a spacing equal to or less than $20 \mathrm{~cm}$. In the earlier code (TEC, 1975), for these requirements, the current reinforced concrete building design standard TS500 is recommended.

According to the Turkish earthquake codes (TEC, 1975, 1998, 2007), the floor slabs should be reinforced concrete plate slabs or joist floors, considering also the relevant
Turkish standards (TS500, 1975, 1982, 1985). Additionally, cantilever elements such as balconies etc. should be constructed as an extension of the floor slab, with at least $1.5 \mathrm{~m}$ span length. It was observed that this requirement was mainly satisfied, as seen in Fig. 24a. But the continuity of the walls in vertical direction was not present, especially where the cantilever balconies were changed to living rooms in use, as also seen in Fig. 24a.

The reinforced concrete band beams recommended should be concurrently constructed with slabs and monolithically 


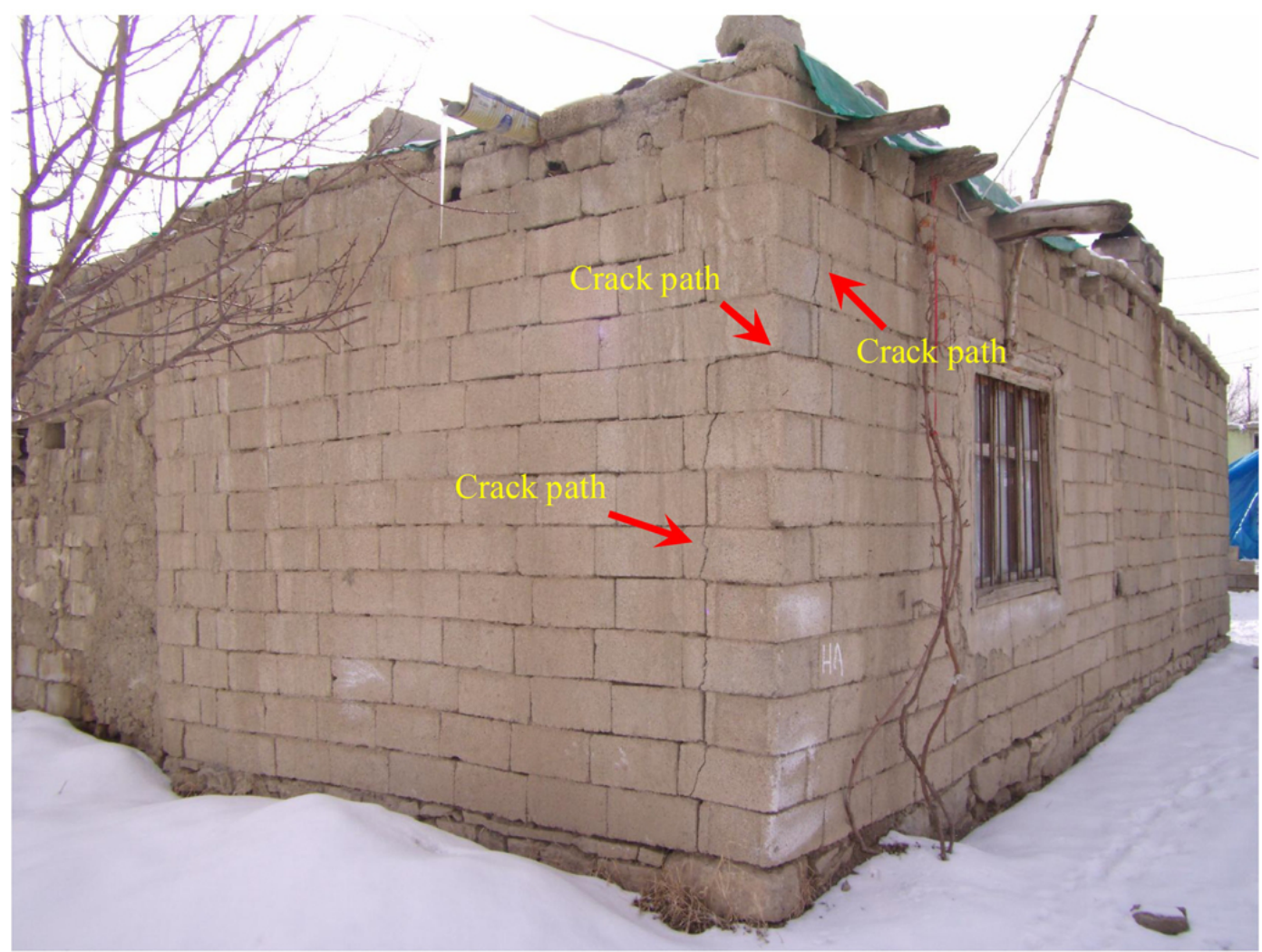

Fig. 23. Crack propagated from one wall to the other in perpendicular direction at the building corner.

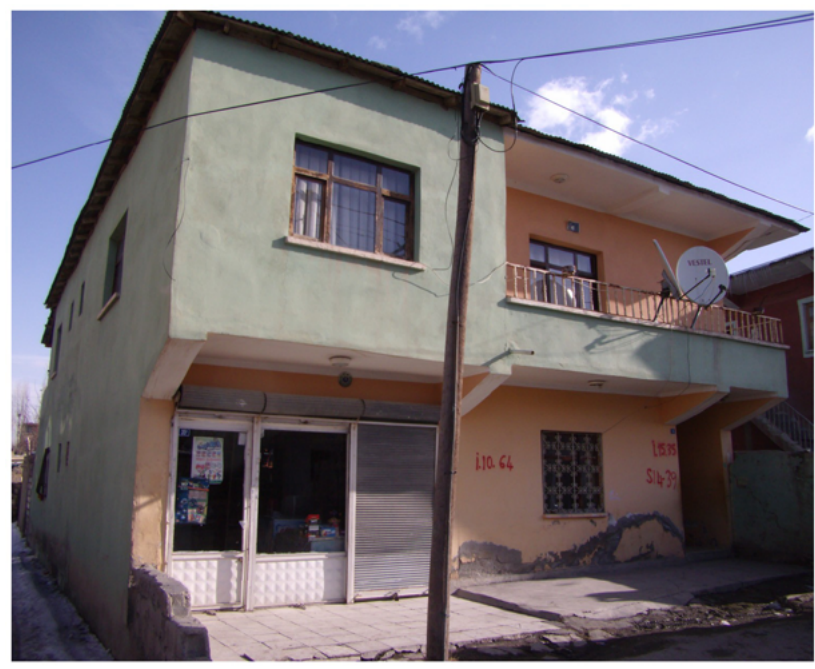

a

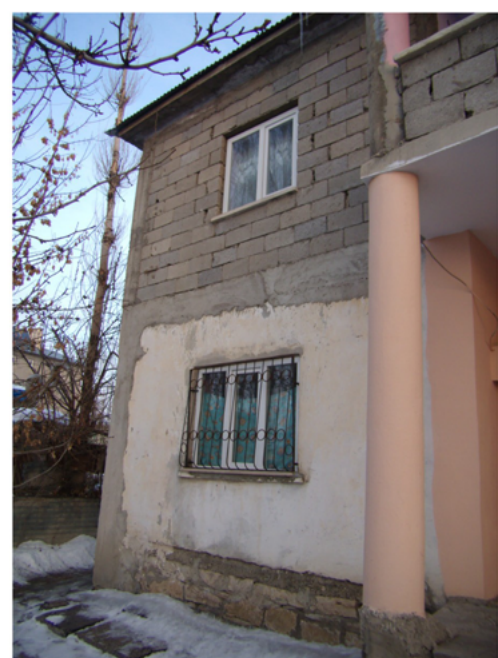

b

Fig. 24. Views of typical confined masonry buildings.

poured, with concrete having the same thickness of the wall and at least $20 \mathrm{~cm}$ in the other direction of the cross section. The concrete quality required is $\mathrm{C} 16$ in the last code (TEC, 2007), C14 in the previous code (TEC, 1998) or even C12 in the earlier code (TEC, 1975). For the longitudinal reinforcement in the band beams, 4 rebars of at least $10 \mathrm{~mm}$ diameter are a requirement of the seismic codes (TEC, 1975, 1998, 2007) where 6 rebars with a minimum $10 \mathrm{~mm}$ diameter are required for the stone walls (TEC, 1998, 2007). The diameter of the stirrups should be at least $8 \mathrm{~mm}$ in the last two 


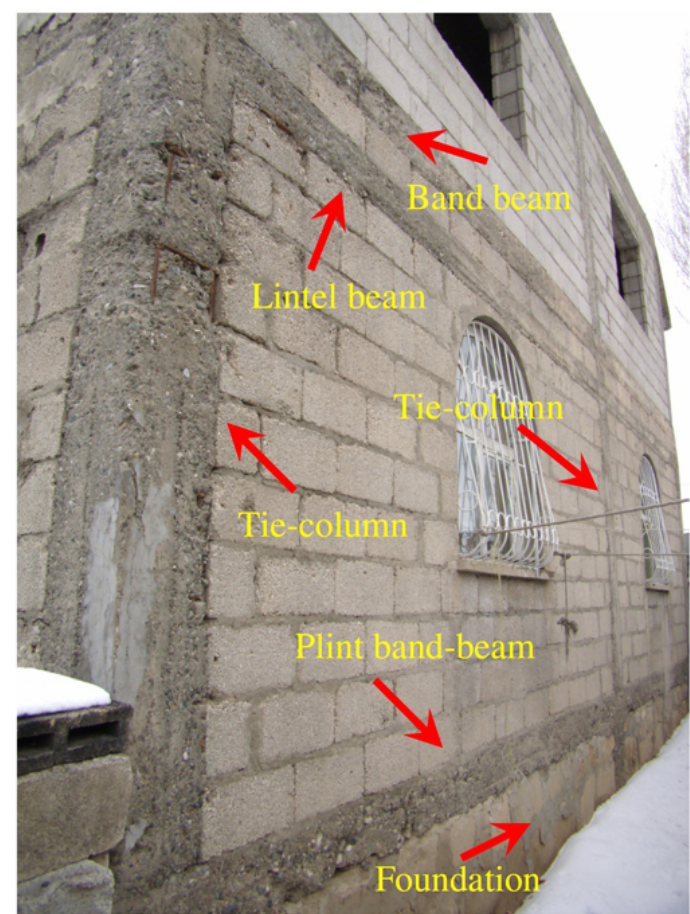

a

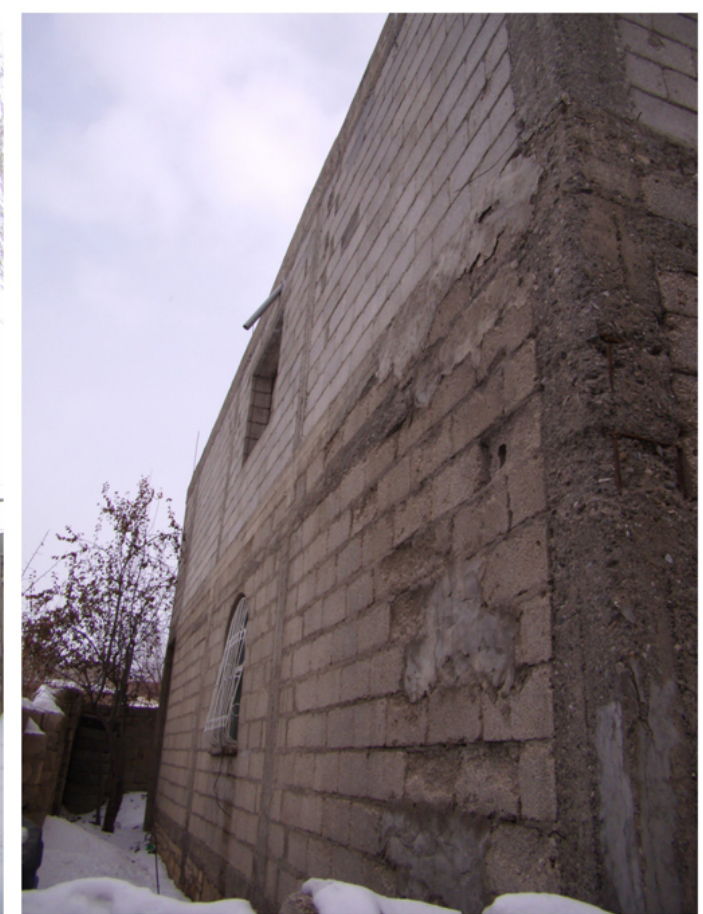

b

Fig. 25. Views of a typical confined masonry building and its structural members.

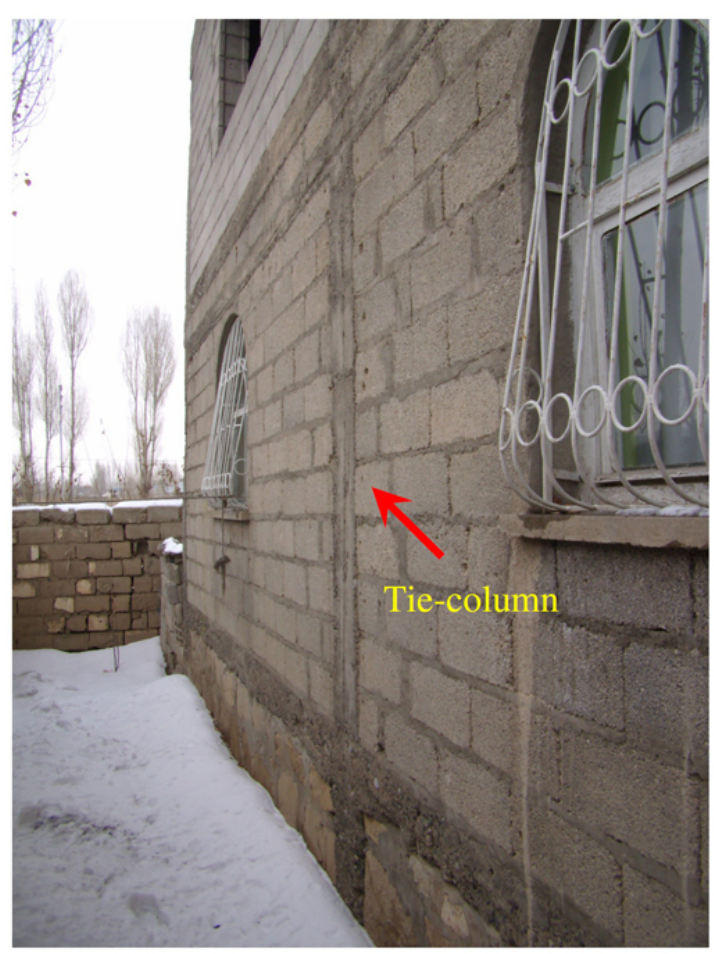

a

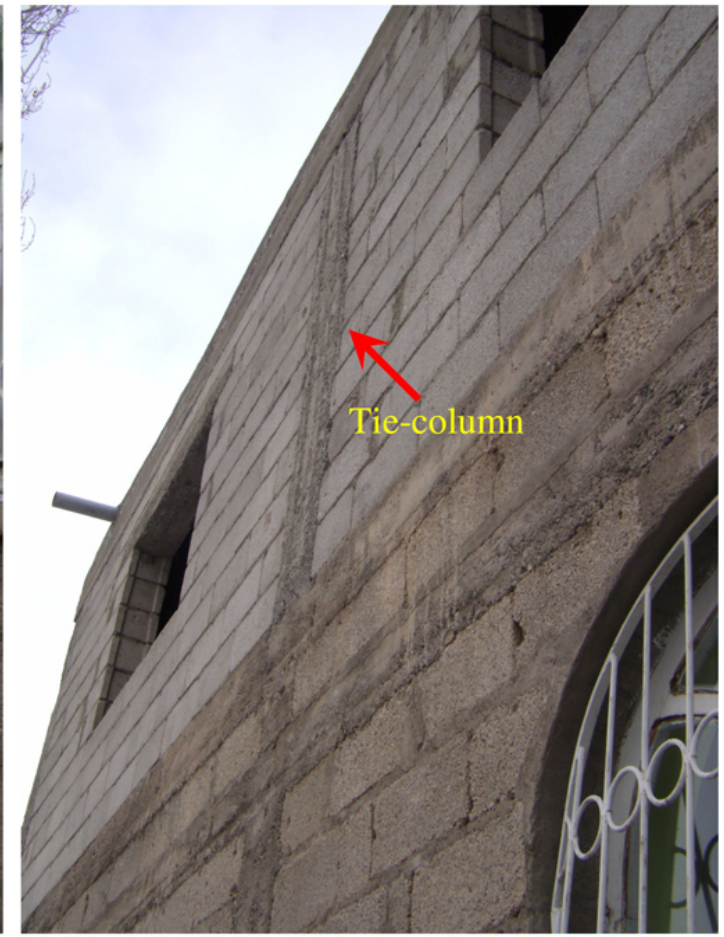

b

Fig. 26. Closer views of a confined masonry building. 


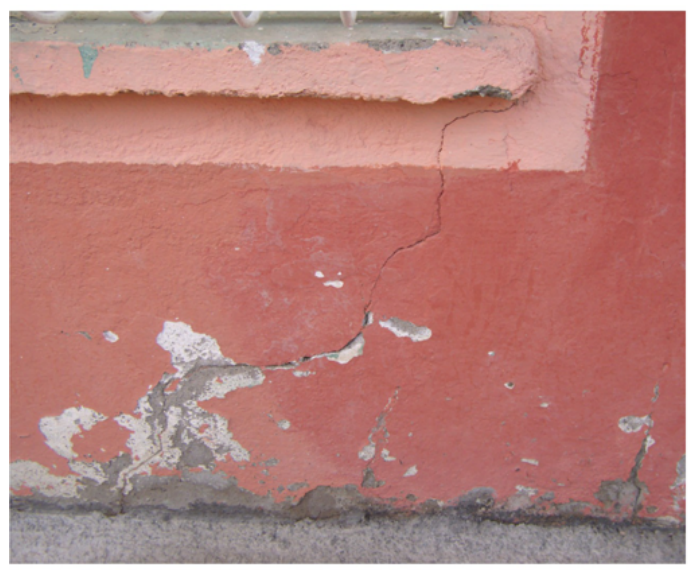

a

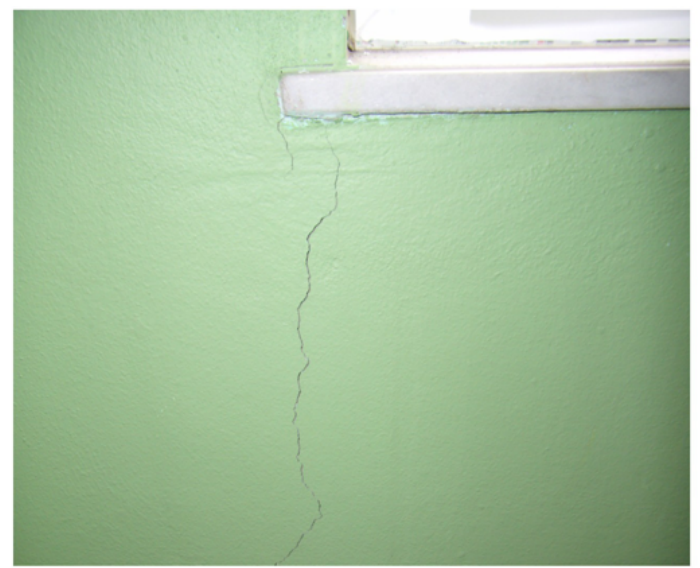

b

Fig. 27. Slight cracks at sill parts of window openings.

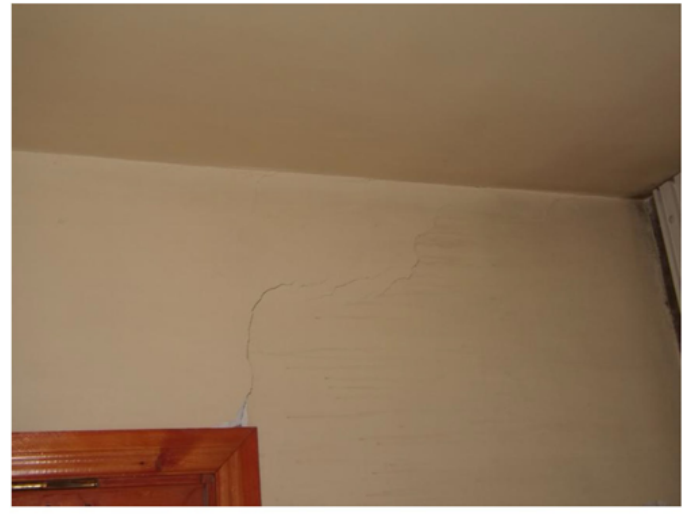

a. Cracks at the corner of a door opening

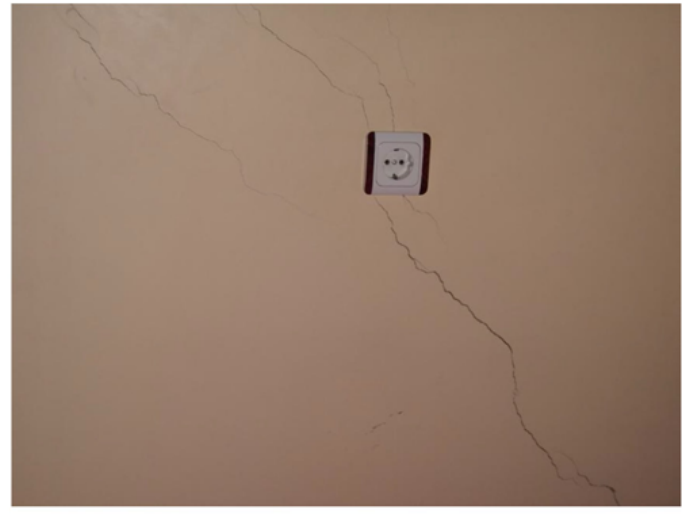

b. Diagonal cracks at the wall

Fig. 28. Slight damages in a confined masonry building.

codes (TEC, 1998, 2007) and $6 \mathrm{~mm}$ in the earlier code (TEC, 1975), with a spacing equal to or less than $25 \mathrm{~cm}$ (TEC, 1998, 2007). Additionally, it was observed that the anchorages of the longitudinal rebars of the tie columns and band beams were very poor due to the inadequate workmanship in these regions.

\section{Summary and conclusions}

In this study, the seismic damages to the masonry buildings after the 23 October and 9 November 2011 Van earthquakes are investigated. The masonry buildings are classified as adobe, unreinforced and confined masonry buildings which were traditionally constructed with poor workmanship by the owners or regional craftsmen regardless of the requirements of current earthquake resistant masonry building design codes and engineering judgement. The seismic performance of these buildings in the Hacibekir district of Van city, which was one of the regions affected by the two consecutive earthquakes heavily, were observed and evaluated, as given in Table 1. Unlike other studies in relevant literature, based on the site observations, the interpretations of the masonry buildings of three types were highlighted, illustrated and commented on in detail in terms of structural strength, seismic performance and requirements of the Turkish earthquake codes.

Depending on the site investigations, it is observed that while the adobe and the unreinforced buildings were seriously damaged by the cracks and gaps developed between the load-bearing walls and by the partial collapses of the heavy flat roof systems, the confined masonry buildings usually showed good performance, having only minor cracks occur at the masonry walls and at their window or door openings.

As a result of this study, it is seen that using appropriate slabs that act like a diaphragm and proper connections and anchorages for the continuity are important to uniformly transfer the earthquake induced lateral forces. Additionally, 
Table 1. Field observations and recommendations.

\begin{tabular}{|c|c|c|c|}
\hline Definition & Turkish earthquake codes & Field observation & Recommendation \\
\hline Number of stories & $\begin{array}{l}\text { Max. one story excluding basement for } \\
\text { adobe buildings, } 2-4 \text { stories with one } \\
\text { basement for masonry buildings }\end{array}$ & $\begin{array}{l}\text { One story for adobe and unreinforced ma- } \\
\text { sonry (URM) buildings, } 2-3 \text { stories for } \\
\text { confined masonry (CM) buildings }\end{array}$ & $\begin{array}{l}\text { Limitations given in the current } \\
\text { code should be provided }\end{array}$ \\
\hline Story height & $\begin{array}{l}\text { Max. } 2.7 \mathrm{~m} \text { for adobe buildings, } \\
\text { Max. } 3 \mathrm{~m} \text { for masonry building }\end{array}$ & Suitability was observed & Limitations should be appropriate \\
\hline $\begin{array}{l}\text { Structural symmetry in } \\
\text { plan }\end{array}$ & $\begin{array}{l}\text { is needed regarding the two principal axis } \\
\text { of the building and partial/semi-basement } \\
\text { is not allowed }\end{array}$ & $\begin{array}{l}\text { Suitability was observed for one axis in } \\
\text { adobe and masonry buildings and semi- } \\
\text { basement in CM }\end{array}$ & $\begin{array}{l}\text { Symmetry is needed to prevent } \\
\text { cracks developed due to torsional } \\
\text { moments and no semi-basement. }\end{array}$ \\
\hline $\begin{array}{l}\text { Vertical continuity of } \\
\text { bearing walls }\end{array}$ & This requirement should be fulfilled & Cracks due to superimposed loads in CM & $\begin{array}{l}\text { No change of balconies to living } \\
\text { rooms }\end{array}$ \\
\hline $\begin{array}{l}\text { Material and compres- } \\
\text { sion strength of bearing } \\
\text { walls }\end{array}$ & $\begin{array}{l}\text { Concrete briquettes with holes and light } \\
\text { aggregated concrete masonry units are } \\
\text { not allowed, min. } 5 \mathrm{MPa} \text { strength }\end{array}$ & Suitability was not observed & $\begin{array}{l}\text { Use of proper materials given in the } \\
\text { current code }\end{array}$ \\
\hline $\begin{array}{l}\text { Mortar volumetric ratios } \\
\text { for load-bearing walls }\end{array}$ & $\begin{array}{l}C: S=1: 3 \text { or } C: L: S=1: 2: 9 \text { for } \\
\text { adobe buildings and } C: S=1: 4 \text { or } \\
C: L: S=1: 2: 9 \text { for masonry buildings }\end{array}$ & $\begin{array}{l}\text { Poor quality of mortar, even mud mortar } \\
\text { were observed }\end{array}$ & $\begin{array}{l}\text { Given ratios should be followed to } \\
\text { avoid zig-zag path of cracks }\end{array}$ \\
\hline $\begin{array}{l}\text { Wall thicknesses for } \\
\text { foundation wall }\end{array}$ & $\begin{array}{l}\text { Min. thickness of } 50-60 \mathrm{~cm} \text { and height of } \\
50 \mathrm{~cm} \text { from the ground for rubble stone or } \\
\mathrm{RC} \text { walls with min. } 25 \mathrm{~cm} \text { thickness and } \\
\mathrm{C} 16 \text { concrete quality in masonry build- } \\
\text { ings }\end{array}$ & $\begin{array}{l}\text { Rubble stone walls with thickness of } 50 \mathrm{~cm} \\
\text { and height of } 30-50 \mathrm{~cm} \text { from the ground } \\
\text { were observed in masonry buildings }\end{array}$ & $\begin{array}{l}\text { Provide appropriate wall thick- } \\
\text { nesses given in the current code }\end{array}$ \\
\hline $\begin{array}{l}\text { Wall thicknesses for } \\
\text { load-bearing walls }\end{array}$ & $\begin{array}{l}1.5 \text { times of adobe unit for exterior walls } \\
\text { and } 1 \text { times adobe unit for interior walls } \\
\text { in adobe buildings and min } 20-40 \mathrm{~cm} \\
\text { or } 1-1.5 \text { times of brick unit in masonry } \\
\text { buildings }\end{array}$ & $\begin{array}{l}\text { Min } 1 \text { brick unit for bearing wall was ob- } \\
\text { served and } 40-50 \mathrm{~cm} \text { were measured for } \\
\text { stone walls }\end{array}$ & $\begin{array}{l}\text { Provide appropriate } \\
\text { wall thicknesses given } \\
\text { in the current code }\end{array}$ \\
\hline $\begin{array}{l}\text { Plan length of a solid } \\
\text { bearing wall }\end{array}$ & $\begin{array}{l}\text { Max. } 4-4.5 \mathrm{~m} \text { for adobe buildings, } \\
\text { Max. } 5.5-7.5 \mathrm{~m} \text { for masonry buildings }\end{array}$ & Suitability was mostly observed & $\begin{array}{l}\text { Provide limits given to enhance } \\
\text { shear/flexural wall strength. }\end{array}$ \\
\hline $\begin{array}{l}\text { Wall length from open- } \\
\text { ing to the building corner }\end{array}$ & $\begin{array}{l}\text { Min. } 1 \mathrm{~m} \text { for adobe buildings, } \\
\text { Min. } 1.5 \mathrm{~m} \text { for masonry buildings }\end{array}$ & Suitability was mostly observed & $\begin{array}{l}\text { Use of tie columns to reduce cracks } \\
\text { and gaps }\end{array}$ \\
\hline $\begin{array}{l}\text { Wall length between the } \\
\text { openings }\end{array}$ & $\begin{array}{l}\text { Min. } 0.60-1 \mathrm{~m} \text { for adobe buildings } \\
\text { Min. } 0.80-1 \mathrm{~m} \text { for masonry buildings }\end{array}$ & Suitability was mostly observed & $\begin{array}{l}\text { Follow limits or use lintel, sill } \\
\text { beams and tie columns to reduce } \\
\text { cracks }\end{array}$ \\
\hline $\begin{array}{l}\text { Wall length between } \\
\text { opening and corner of } \\
\text { intersecting walls }\end{array}$ & $\begin{array}{l}\text { Min. } 0.50 \mathrm{~m} \text { adobe and masonry build- } \\
\text { ings }\end{array}$ & $\begin{array}{l}\text { Suitability was not observed for door open- } \\
\text { ings }\end{array}$ & $\begin{array}{l}\text { Use of lintel, sill beams and tie } \\
\text { columns to reduce cracks }\end{array}$ \\
\hline $\begin{array}{l}\text { Opening's plan length } \\
\text { for doors and windows }\end{array}$ & $\begin{array}{l}\text { Max. } 0.9-2.1 \mathrm{~m} \text { for adobe buildings, } \\
\text { Max. } 3 \mathrm{~m} \text { for masonry buildings }\end{array}$ & Suitability was mostly observed & Limitations should be satisfied. \\
\hline $\begin{array}{l}\text { Lintel and sill beams } \\
\text { under and/or above } \\
\text { openings }\end{array}$ & $\begin{array}{l}\text { Timber lintels }(10 \mathrm{~cm} \times 10 \mathrm{~cm}) \text { for adobe } \\
\text { buildings and seating length of lintels on } \\
\text { walls more than } 20 \mathrm{~cm} \text { for masonry build- } \\
\text { ings }\end{array}$ & $\begin{array}{l}\text { Cracks due to absence of lintel/ sill beams } \\
\text { were observed }\end{array}$ & $\begin{array}{l}\text { Appropriate lintel/sill beams should } \\
\text { be used to reduce cracks and to im- } \\
\text { prove wall strength }\end{array}$ \\
\hline $\begin{array}{l}\text { Horizontal plinth band } \\
\text { beams on the foundation }\end{array}$ & $\begin{array}{l}\text { Timber }(10 \mathrm{~cm} \times 10 \mathrm{~cm}) \text { or } \mathrm{RC} \text { band } \\
\text { beams with min. height of } 15 \mathrm{~cm} \text { for } \\
\text { adobe buildings and } \mathrm{RC} \text { band beams for } \\
\text { masonry buildings }\end{array}$ & $\begin{array}{l}\text { No proper connections, anchorages and no } \\
\text { plinth band beam on top of foundation, but } \\
\text { plinth band beams in CM were observed }\end{array}$ & $\begin{array}{l}\text { Band beams should be used to pre- } \\
\text { vent settlements, and to provide lat- } \\
\text { eral resistance and structural in- } \\
\text { tegrity }\end{array}$ \\
\hline
\end{tabular}

band beams at plinth, lintel and roof levels as well as vertical tie columns, especially on corners, should enhance the shear and flexural load-carrying capacities of bearing walls, and thus no or at most minor cracks will develop even in the first and second seismic zones. Following these factors, the masonry building will act as a box-type structural system which behaves like a box, and thus, the performance of these buildings will be enhanced due to the increased earthquake resistance.
On the other hand, it is possible to repair and retrofit the minor and also moderate damaged masonry buildings by using appropriate techniques. Using installation of vertical columns as well as band beams at roof and slab levels, a box-like behaviour can be achieved for masonry buildings. In order to reinforce the wall-to-wall and wall-to-floor connections, installing metallic ties is another applicable method. Shotcreting the load-bearing walls is a wide-spread method to strengthen these walls by using a steel mesh or polymer grid sprayed by cement-aggregate mix with a concrete 
Table 1. Continued.

\begin{tabular}{|c|c|c|c|}
\hline Definition & Turkish earthquake codes & Field observation & Recommendation \\
\hline $\begin{array}{l}\text { Horizontal band beams } \\
\text { under the roof slab }\end{array}$ & $\begin{array}{l}\text { Timber band beams }(10 \mathrm{~cm} \times 10 \mathrm{~cm}) \text { for } \\
\text { adobe buildings and } \mathrm{RC} \text { band beams with } \\
\text { min. height of } 20 \mathrm{~cm} \text { for masonry build- } \\
\text { ings }\end{array}$ & $\begin{array}{l}\text { No proper connections and } \\
\text { anchorages, no band beam at roof level for } \\
\text { adobe and URM buildings was observed }\end{array}$ & $\begin{array}{l}\text { Band beams should be used to pro- } \\
\text { vide proper lateral distribution of } \\
\text { seismic loads and to act as a box of } \\
\text { masonry walls }\end{array}$ \\
\hline $\begin{array}{l}\text { Horizontal band beams } \\
\text { on the load-bearing walls }\end{array}$ & $\begin{array}{l}\text { RC band beams with BS } 16 \text { concrete } \\
\text { quality and min. height of } 20 \mathrm{~cm} \text { cast } \\
\text { monolithically with the reinforced con- } \\
\text { crete slab at places where each of the } \\
\text { slabs is for confined masonry buildings }\end{array}$ & $\begin{array}{l}\text { Cracks and gaps of } 10 \mathrm{~cm} \text { developed due to } \\
\text { the lack of band beams in URM, } \\
\text { adequate section sizes, but low concrete } \\
\text { quality for band beams in CM }\end{array}$ & $\begin{array}{l}\text { Should be used to provide proper } \\
\text { lateral distribution of seismic loads } \\
\text { and to enhance lateral resistance and } \\
\text { structural integrity }\end{array}$ \\
\hline $\begin{array}{l}\text { Vertical reinforced } \\
\text { concrete tie columns }\end{array}$ & $\begin{array}{l}\text { RC tie columns with BS } 16 \text { concrete } \\
\text { quality and min. height of } 20 \mathrm{~cm} \text { on cor- } \\
\text { ners of the building and along the ver- } \\
\text { tical intersection of the bearing walls in } \\
\text { full story height and on both sides of the } \\
\text { openings. Wall length can be increased to } \\
\text { max. } 16 \mathrm{~m} \text { by using ties with } 4 \mathrm{~m} \text { spacings. }\end{array}$ & $\begin{array}{l}\text { Observed only on corners in CM; concrete } \\
\text { qualities were low but sizes of their cross } \\
\text { section were suitable }\end{array}$ & $\begin{array}{l}\text { Should be used to improve the sta- } \\
\text { bility of walls and to enhance lateral } \\
\text { wall resistance }\end{array}$ \\
\hline $\begin{array}{l}\text { Slabs and length of the } \\
\text { cantilever extension for } \\
\text { slabs such as balconies } \\
\text { and stairs }\end{array}$ & $\begin{array}{l}\text { Length is less than } 1.0 \mathrm{~m} \text { for stairs and } \\
1.5 \mathrm{~m} \text { for balconies if } \mathrm{RC} \text { slab is used }\end{array}$ & $\begin{array}{l}\text { Plaster spalling, vertical cracks under } \\
\text { wooden logs in URM and cracks in slabs } \\
\text { due to low concrete quality in } \mathrm{CM}\end{array}$ & $\begin{array}{l}\text { Avoid from long cantilever exten- } \\
\text { sions to fulfill vertical continuity } \\
\text { and increase lateral wall rigidity }\end{array}$ \\
\hline Roof & $\begin{array}{l}\text { No soil roof for the first and second } \\
\text { seismic zones, otherwise min. } 15 \mathrm{~cm} \text { soil } \\
\text { layer thickness should be used. }\end{array}$ & $\begin{array}{l}\text { Collapses due to soil heavy roofs, roofs of } \\
\text { thick mud or earth layers on wooden logs } \\
\text { and poor connection detail between roof } \\
\text { and walls were observed }\end{array}$ & $\begin{array}{l}\text { Avoid use of soil roof due to weight, } \\
\text { provide appropriate roof-slab and } \\
\text { wall connections, and use band } \\
\text { beam at roof level }\end{array}$ \\
\hline
\end{tabular}

pump. Reinforcing, which refers to steel reinforcing bars at corners of walls, is another method to retrofit the loadcarrying capacity of a bearing wall. For small to moderate cracks, grouting with cement paste or epoxy is a very easy technique to apply in practice.

In the future it is planned to develop the computer models of these three types of masonry buildings in order to study their earthquake-induced dynamic behavior and failure modes in more detail, and thus to evaluate and/or enhance the most appropriate retrofitting technique.

Acknowledgements. The authors wish to acknowledge the AFAD of the Van government and the Earthquake Engineering and Disaster Management Institute of Istanbul Technical University for the organization and the financial support provided during site investigations. The authors also would like to thank Deniz Oz, for her contributions during the seismic damage investigations of the buildings. In this paper all the interpretations and conclusions drawn from the field study belong to the authors alone.

Edited by: M. E. Contadakis

Reviewed by: E. Aydin and one anonymous referee

\section{References}

Baran, E., Mertol, H. C., and Gunes, B.: Damage in reinforced concrete buildings during October 23 and November 9, 2011 Van, Turkey Earthquakes, Journal of Performance of Construction Facilities, Am. Soc. Civil. Eng., Preview Manuscript, doi:10.1061/(ASCE)CF.1943-5509.0000396, in press, 2012.

Bayraktar, A., Coskun, N., and Yalcin, A.: Damages of masonry buildings during the July 2, 2004 Dogubayazit (Agri) earthquake in Turkey, Eng. Failure Analys., 14, 147-157, 2007.

Bayraktar, A., Altunisik, A. C., and Muvafik, M.: Field investigation on the performance of masonry buildings during the October 23 and November 9, 2011 Van Earthquakes in Turkey, Journal of Performance of Construction Facilities, Preview Manuscript, doi:10.1061/(ASCE)CF.1943-5509.0000383, in press, 2012.

Binici, H.: March 12 and June 6, 2005 Bingol-Karliova earthquakes and the damages caused by the material quality and low workmanship in the recent earthquakes, Eng. Failure Analys., 14, 233-238, 2007.

Bruneau, M.: State-of-the-art report on seismic performance of unreinforced masonry buildings, J. Struct. Eng., 120, 230-251, 1994.

Bruneau, M. and Yoshimura, K.: Damage to masonry buildings caused by the 1995 Hyogo-ken Nanbu (Kobe, Japan) earthquake, Can. J. Civil Eng., 23, 797-807, 1996.

Celep, Z., Erken, A., Taskin, B., and Ilki A.: Failures of masonry and concrete buildings during the March 8, 2010 Kovancilar and Palu (Elazig) Earthquakes in Turkey, Eng. Failure Analys., 18, 868-889, 2011.

Center for Disaster Management and Risk Reduction Technology (CEDIM): available at: http://www.cedim.de, 2012. 
Cetinkaya, N.: 2010 Karakocan-Elazig earthquake and masonry structures, Nat. Hazards Earth Syst. Sci., 11, 11-16, doi:10.5194/nhess-11-11-2011, 2011.

Disaster and Emergency Management Presidency of Turkey (AFAD): available at: http://www.afad.gov.tr, 2012.

Furukawa, A. and Ohta, Y.: Failure process of masonry buildings during earthquake and associated casualty risk evaluation, Nat. Hazards, 49, 25-51, 2009.

Global Seismic Hazard Assessment Program (GSHAP), available at: http://www.seismo.ethz.ch/static/gshap/turkey, 2012.

Güney, D.: Van earthquakes (23 October 2011 and 9 November 2011) and performance of masonry and adobe structures, Nat. Hazards Earth Syst. Sci., 12, 3337-3342, doi:10.5194/nhess-123337-2012, 2012.

Housing Development Administration of Turkey (TOKI): available at: http://www.toki.gov.tr, 2012.

Kaplan, H., Yilmaz, S., Binici, H., Yazar, E., and Cetinkaya, N.: May 1, 2003 Turkey-Bingol earthquake: damage in reinforced concrete structures, Eng. Failure Analys., 11, 279-291, 2004.

Klingner, R. E.: Behavior of masonry in the Northridge (US) and Tecoman-Colima (Mexico) earthquakes: Lessons learned, and changes in US design provisions, Construct. Build. Materials, 20, 209-219, 2006.

Okuyucu, D., Kale, O., Erdil, B., Caner, A., Askan, A., and Akansel, V. H.: Evaluation of Turkish seismic bridge design practice resulting in a successful seismic performance of highway bridges during the 23 October 2011 Van Earthquake, $\mathrm{Mw}=7.1$, J. Performance Construct. Facil., Preview Manuscript, available at: http://ascelibrary.org/doi/pdf/10.1061/\%28ASCE\% 29CF.1943-5509.0000377, 2012.
Sayın, E., Yön, B., Calayır, Y., and Karaton, M.: Failures of masonry and adobe buildings during the June 23, 2011 Maden (Elazig) earthquake in Turkey, Eng. Failure Analys., doi:10.1016/j.engfailanal.2012.10.016, in press, 2012.

The Governorship of Van: available at: http://www.van.gov.tr, 2012.

Turkish Earthquake Code (TEC): Specification for structures to be built in disaster areas, Government of Republic of Turkey, Ministry of Public Works and Settlement, Ankara, 1975.

Turkish Earthquake Code (TEC): Specification for structures to be built in disaster areas, Government of Republic of Turkey, Ministry of Public Works and Settlement, Ankara, 1998.

Turkish Earthquake Code (TEC): Specification for buildings to be constructed in earthquake areas, Government of Republic of Turkey, Ministry of Public Works and Settlement, Ankara, 2007.

TS EN 771-1: Specification for masonry units, TSE Turkish Standards Institution, Ankara, 2011.

TS2510: Specification for the design and construction methods for masonry, TSE Turkish Standards Institution, Ankara, 1977.

TS500: Specification for design and construction of reinforced concrete structures, TSE Turkish Standards Institution, Ankara, 1975.

TS500: Specification for design and construction of reinforced concrete structures, TSE Turkish Standards Institution, Ankara, 1982.

TS500: Specification for design and construction of reinforced concrete structures, TSE Turkish Standards Institution, Ankara, 1985.

TS705: Specification for the solid bricks and vertically perforated bricks, TSE Turkish Standards Institution, Ankara, 1985.

US Geological Survey (USGS): available at: http://www.usgs.gov, 2012. 